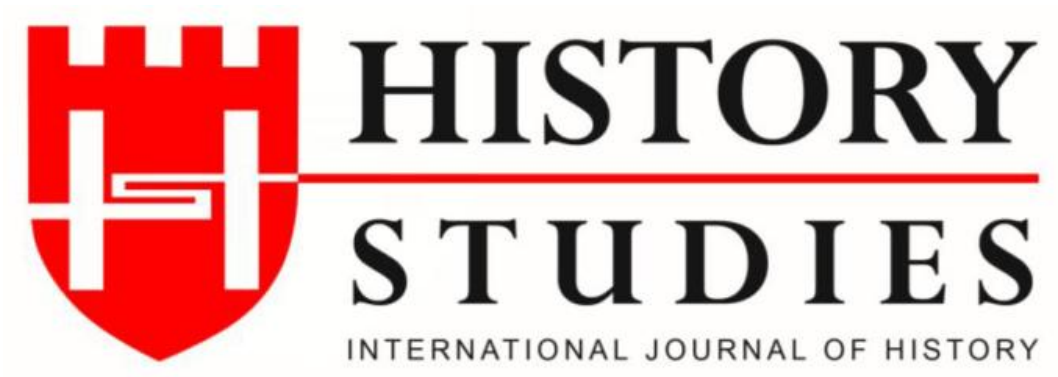

\author{
ISSN: 13094173 (Online) 1309 - 4688 (Print) \\ Volume 12 Issue 6, December 2020 \\ DOI Number: 10.9737/hist.2020.953 \\ Araştırma Makalesi
}

Makalenin Geliş Tarihi: 26.08.2020 Kabul Tarihi: 24.09.2020

Atıf Künyesi: Kaya Göktepe, “Osmanlı Sosyoekonomik Hayatında Uyuşturucu Madde Kaynaklarının Arz Boyutu: Haşhaş ve Kenevir Bitkisi", History Studies, 12/6, Aralık 2020, s. 3031-3055.

\title{
Osmanlı Sosyoekonomik Hayatında Uyuşturucu Madde Kaynaklarının Arz Boyutu: Haşhaş ve Kenevir Bitkisi
}

\section{Supply Dimensions of Drugs Sources in the Ottoman Socio-economic Life: Poppy and Hemp Plant}

\author{
Dr. Kaya Göktepe \\ ORCID No: 0000-0001-7613-2083 \\ İstanbul Medeniyet Üniversitesi
}

$\ddot{O} z$

Haşhaş ve kenevir, tarihsel süreç içerisinde farklı alanlarda talep gören bitkiler olarak dikkati çekmiştir. Bu bitkiler içerisinde haşhaştan elde edilen afyon ile kenevirden elde edilen esrar, farklı alanlara hitap etmiş olsa da bazı alanlarda ortak kullanıma sahiptir. Bunların başında, her iki bitkinin de uyuşturucu özelliği nedeniyle tıbbî sahada ağrı giderici ve tedavi edici özellikleri yanında, keyif amacıyla kullanılan ve talep gören ürünler olmasidir.

Eski toplumlarda olduğu gibi Osmanlı toplumunda da afyon ve esrar bir taraftan sağlık sektörünün vazgeçilmez ürünleri olmuş diğer taraftan da gizli bir şekilde keyif amacıyla kullanılmıştır. Afyon ve esrarın farklı amaçlarla kullanılması ise her bir amaca uygun arz ve talep piyasanın oluşmasını sağlamıştır. Bu süreçte Osmanlı Devleti'nde afyon ve esrar maddelerinin sağlı sektöründe kullanılması amaçlandığı için üretimden başlayarak, pazarlama ve satış süreçlerini de içine alan bir piyasa düzeni oluşturulmaya gayret edilmiştir. Buna karşı keyif amacıyla kullanıma yönelik ise mücadele politikaları benimsenmiştir. Osmanlı ekonomik ve toplumsal hayatında önemli yeri olan haşhaş ve kenevir bitkisini uyuşturucu madde arzı boyutuyla ele alan bu çalışma, uyuşturucu maddeye kaynaklık eden afyon ve esrarı, Osmanlı sosyoekonomik yapısı çerçevesinde tahlil etmeyi amaçlamaktadır.

Anahtar Kelimeler: Arz, Uyuşturucu, Afyon, Esrar, Osmanlı.

\begin{abstract}
Poppy and hemp have attracted attention as plants that are in demand in different areas in the historical process. Although among these plants, opium obtained from poppy and cannabis obtained from hemp addressed to different areas they have common use in some areas. First of all, because of the sedative properties of both herbs, they are used and demanded for pleasure purposes, besides the pain relieving and therapeutic properties in the medical field.

As in old societies, in Ottoman society, opium and cannabis are indispensable products of the health sector on the one hand, and on the other hand, they are used secretly for pleasure. The use of opium and cannabis for different purposes enabled the supply and demand market suitable for each purpose. In this process, as the opium and cannabis materials were intended to be used in the health sector in the Ottoman Empire, an effort
\end{abstract}


was made to create a market order that includes marketing and sales processes, starting with production. On the other hand, fight policies have been adopted against the use for pleasure. This study, which deals with poppy and hemp plants, which have an important place in Ottoman economic and social life, with their drug supply dimension, aims to analyze poppy and hemp that are sources of drugs within the framework of Ottoman socioeconomic structure.

Keywords: Supply, Drug, Opium, Cannabis, Ottoman.

\section{Giriș}

Tarih boyunca insanoğlu, hâsıl olan ihtiyaçlarını karşılamak ve hayatını idame ettirebilmek için ekonomik faaliyetlerde bulunmuş, ekonomik faaliyetlerde bulunurken de bir topluluk içinde yaşamış olmanın getirdiği koşulların etkisiyle toplumsal norm ve değerlere uygun hareket etmeye gayret etmiştir. İnsanoğlu, toplumsal norm ve değerlere uygun hareket etmek isterken de geçmiş tecrübelerden ve geleneklerden beslenmeye çalışmış ve bundan dolayı insanın hayatını idame ettirebilmesine yönelik birçok faaliyet, sosyokültürel koşulların etkisi altında meydana gelmiştir.

İnsanların ve toplumların sosyoekonomik faaliyetlerde bulunurken geçmiş tecrübelerden ve sosyokültürel koşullarda önemli ölçüde etkilendiği hususu, Osmanlı toplumu için de geçerliliğini korumuştur. Bu noktada Osmanlı ekonomik ve toplumsal hayatı da diğer Türk-İslâm medeniyetlerinin devamı niteliğindeki yapısıyla dikkati çekmiş olup üretim biçimleri, ekilen ürün türleri, ürünlere yönelik tüketim alışkanlıkları gibi birçok iktisadî unsurun yanı sıra, sağlık alanındaki tıbbî tedavi yöntemlerinde ve kullanılan ilaçlarda geçmişin izleri açıkça görülmüştür. Nitekim devamlılığın bir parçası olarak, özellikle iktisadî bir gelir kaynağı ve aynı zamanda sağlık alanında faydaları görülen uyuşturucu niteliğindeki bazı bitkiler, Osmanlı sosyoekonomik hayatında önemli bir yere sahip olmuştur.

Uyuşturucu madde bilindiği üzere üretim ve tüketime konu olması itibarıyla eski çağlara kadar uzanan bir geçmişi bünyesinde taşımaktadır. Maddeler içerisinde özellikle haşhaştan elde edilen afyon ile kenevirden elde edilen esrar; Mısır, Hint, Çin, Yunan, Roma ve İslam dünyasına kadar geniş bir tarihi arka planı içinde barındırmaktadır. ${ }^{1}$ Bunlar içerisinde özellikle haşhaştan elde edilen afyon, eski uygarlıklarda olduğu gibi Türk-İslâm toplumlarında da hekimlerin tıbbî amaçlarla tedavi edici ve ağrı giderici olarak başvurdukları önemli şifa kaynakları arasında yer almıştır. $^{2}$

Türk-İslâm medeniyetlerinde olduğu gibi Osmanlı toplumunda da uyuşturucu maddelerin kaynağını oluşturan bitkiler içerisinde özellikle haşhaş ve kenevir bitkisine tıbbî alanda ciddi talep gerçekleşmiştir. Bunlar içerisinde Osmanlı toplumunda "beng" adıyla zikredilen esrarın yanı sıra afyon ve afyon karışımları, toplumun geneli tarafından benimsenerek anestetik amaçlarla çeşitli ağrının, sızının tedavisinde ve öksürük gibi rahatsızlıklarda yumuşatıcı olarak

\footnotetext{
${ }^{1}$ Rüya Kılıç,. “"Afyonun Keyfini Tiryakisinden Sormalı": Osmanlı ve Erken Cumhuriyet'te Madde Bağımlılığı Tarihi", Kebikeç. S. 42, 2016, s. 147-148; Mustafa Baktır," Afyon", Türkiye Diyanet Vakfi İslâm Ansiklopedisi (DIA), Türkiye Diyanet Vakfı Yayınları (TDV Yay.), C. 1, İstanbul 1998, s. 442-443; Turhan Baytop, "Esrar", DİA, TDV Yay., C. 11. İstanbul 1995, s. 431-432.

2 Türk-İslâm tarihinin büyük hekimi İbn-i Sina da afyonun başta analjezik yani ağrı kesici ve hipnotik yani uyku getirici özelliklere sahip olduğunu kaydetmiş ve tıbbî alanda yaygın şekilde afyon kullanmıştır. Ahmed Ağırakça, "Osmanlı Tibbının Kaynakları", Osmanlılarda Sağlık, Cilt: I, Health in The Ottomans, Editör: Coşkun Yılmaz-Necdet Yılmaz, Biofarma Yayınları, İstanbul 2006, s. 142-144; Yine İbn-i Sina ile aynı dönemde yaşayan büyük İslâm alimi Biruni'de afyonun tedavi edici özellikleri olduğunu ve hekimler dışında kimse tarafından kullanılmaması gerektiğini ifade etmektedir. Sami Hamarneh, "Pharmacy in Medieval Islam And The History of Drug Addiction", Medical History, Volume 16, Issue 3, 1972, p. 230-231; Ali Kürçay, Haşhaş Yetiştirilmesi, Güven Matbaası, Ankara 1962, s. 7-8.
} 
yaygın şekilde kullanılmıştır. ${ }^{3}$ Diğer taraftan Osmanlı Klasik Dönemi'nden itibaren geleneksel usullerle imal edilen afyon, afyon macunları ve şurupları ile esrar türevi ürünler, zengin uyuşturucu içeriğine sahip oldukları için tedavi amacı dışında keyif verici bir madde olarak da piyasaya arz edilmiştir. ${ }^{4}$ Dolayısıyla Osmanlı toplumunda afyon ve esrar ile bu maddelerin karışımından elde edilen ürünlerin keyif verici olarak kullanılması, afyon ve esrarın farklı kullanım alanlarının ortaya çıkmasına zemin hazırlamıs ve talebe uygun bir arz piyasasının oluşmasına imkân sağlamıştır. Doğal olarak ortaya çıkan bu durum, haşhaş ve kenevir bitkisinin Osmanlı ekonomik hayatında halkın önemli bir kesiminin vazgeçilmez bir geçim kaynağı haline gelmiş, devlet de almış olduğu vergilerle bu ziraî yapıyı muhafaza etmeye çalışmıştır.

Osmanlı sosyoekonomik hayatında önemli yeri olan haşhaş ve kenevir bitkisinin yüzyıllarca varlığını korumasında ve zamanla geniş̧leyen bir arz piyasasına sahip olmasında talebin önemli etkisi bulunmaktadır. Özellikle XIX. yüzyılın ilk yarısında Osmanlı ekonomi politikalarında yaşanan değişimle birlikte Avrupa ülkeleri ile olan dış ticaretin artması, bu ürünler içerisinde bilhassa afyon üzerinde dış talebin ağırlık kazanmasını sağladığından ihracat odaklı yeni bakış açısı, arz piyasası üzerinde son derece etkili etkili olmuştur. Bu süreçten sonra artık, Osmanlı topraklarında arz edilen uyuşturucu madde kaynağı bitkilerin sağlık alanında veya keyif amacıyla kullanımına yönelik iktisadî ve sosyal politikalar üzerinde Avrupa'nın etkisi söz konusu olduğundan, sınaî ürün olarak kabul edilmeye başlayan özellikle afyon üzerinde Avrupa eksenli uluslararası politikaların üretim üzerinde belirleyici olduğu dikkati çekmektedir.

Osmanlı sosyoekonomik hayatında farklı kullanımalanları olan ve uyuşturucu maddeye temel teşkil eden haşhaş ve kenevir bitkisini arz boyutuyla ele alan bu çalışma zirai üretim, imalat ve pazarlama-satış süreçleriyle belli bir sisteme dayanan uyuşturucu madde kaynaklarını, Osmanlı iktisadi sistemi çerçevesinde tahlil etmeyi hedeflemektedir. Ayrıca bu bitkilerden elde edilen afyon ve esrar gibi uyuşturucu maddelerin keyif amacıyla kullanımına karşı arzın kontrol altına alınmasına yönelik mücadele politikalarına da dikkat çekilmeye çalışılmaktadır.

\section{Uyuşturucu Madde Kavramı}

Uyuşturucu madde, sağlık alanında ağnı kesici ve tedavi edici özellikleri yanında insanın bedensel ve ruhsal yapısını etkileyen, bunun yanında toplumun ekonomik ve sosyal hayatında tesirler meydana getiren çok boyutlu bir kavram olarak ön plana çıkmaktadır. Uyușturucu maddenin çok boyutu bünyesinde taşıması ise kavramın birçok bilim dalının ilgi alanına girmesine neden olmaktadır.

Uyuşturucu madde, birçok alanı ilgilendiren bir hüviyete sahip olsa da her şeyden önce insan sağlığını ilgilendirdiğinden, maddenin kavramsal çerçevesinin belirlenmesinde tıbbî bakış açısı önemli bir yere sahip olmuştur. Bu noktada kavram, tedavi edici özellikleri nedeniyle eskiden beri tıpta bir tedavi aracı olarak başvurulduğundan ilaç anlamındaki kullanımının yanında günümüzde uyuşturucu maddelerin sürekli yeni türlerinin ortaya çıkması, farklı amaçlarla kullanılmasından dolayı ruhî ve fizikî tahribata yol açması, merkezî sinir sistemini etkilemesi gibi nedenlerle ağırlıklı olarak bağımlılıkla ilişkili olarak kullanılmaktadır. ${ }^{5}$

\footnotetext{
${ }^{3}$ Miri Shefer Mossensohn, Ottoman Medicine: Healing and Medical Institutions, 1500-1700, NY Suny Press, New York Albany 2009, p. 39-40; Afife Mat, "Osmanlı İmparatorluğu'nda Afyonun Tarihi”, Osmanlı Bilimi Araştırmaları, XI/ 1-2, 2009-2010, s. 285-286.

${ }^{4}$ Evliyâ Çelebi Seyahatnâmesi (II. Kitap), haz. Seyit Ali Kahraman ve Yücel Dağl1, Yapı Kredi Yayınları, 5. Baskı, İstanbul 2008, s. 607-608; Turhan Baytop, "Eczacil1k", DİA, C.10, İstanbul 1994, s. 387.

${ }^{5}$ Uyuşturucu kavramı geçmişten beri birçok toplumda ve bilim dalında farklı şekillerde tanımlanan bir kavram olarak dikkati çekmektedir. $\mathrm{Bu}$ kavram Türkçe'de yeni bir kelime olup bunun karşıllğında Arapça ve Farsça'da "muhaddir" (örten, kapayan), Batı dillerinde Yunanca "narke" (uyku) kökünden narkotik kullanılır.
} 
Uyuşturucu madde bağımlılığı ile mücadeleyi ana ilkelerinden biri olarak gören Dünya Sağlık Örgütü'ne (WHO) göre uyuşturucu madde; önüne geçilmez gereksinme yahut arzu, kullandığ miktarı artırma eğilimi, ruhsal, fiziksel bağımlılık hali yaratan maddelere verilen isimdir. ${ }^{6}$ Yine tıbbî açıdan başka bir tanımlamada; uyuşturucu maddeler bedene girdiklerinde ruhsal, davranışsal ve bedensel değişikliklere neden olup bağımlılık yapabilen kimyasal maddelerdir. ${ }^{7}$ Bu tanımlamada da görüldüğü gibi uyușturucu maddeler kișide önüne geçilmez bir bağımlılık durumu oluşturma, ruhî ve fizikî tahribata yol açma, merkezî sinir sistemini etkileme, kullanılan miktarı giderek arttırma gibi eğilimlere sebebiyet verdiğinden bağımlılık ekseninde değerlendirilmektedir.

Yine başka bir tanımlamaya göre madde bağımlılı̆̆ı, kişinin kullandığı maddeyi birçok kez bırakma girişiminde bulunmasına rağmen bırakamaması, giderek madde dozunu arttırması, kullanmayı bıraktığında yoksunluk belirtilerinin ortaya çıkması, zararlarını bilmesine rağmen kullanıma devam etmesidir. ${ }^{8}$ Buradan hareketle bağımlılık yapıcı maddeler ve madde bağımlılı̆̆ı; sentetik ya da doğal tüm maddeleri içine alan, kullanıcısının merkezi sinir sistemi işlevini ve bedensel yapısını etkileyerek ilerleyen süreç içerisinde kalıcı etkiler bırakan, sonrasında bireyde ruhsal ve davranışsal sorunlar oluşturan ve ölümle sonuçlanabilen süreçler bütünü olarak tanımlanabilir. ${ }^{9}$ Bütün bu tanımlamalardan da anlaşıldığı gibi uyuşturucu madde, insan vücuduna tedavi esnasında yarar sağlamasına rağmen bağımlılık durumu oluşturma, sosyal, ekonomik, kültürel, dinî ve ahlaki boyutlarıyla insanlığı etkileyen bir kavram olarak ön plana çıkmaktadır.

\section{Uyuşturucu Madde Kaynakları}

İnsanlık tarihi boyunca çeşitli şekillerde uyuşturucu maddeler ortaya çıkmış olup bunlar elde edildiği kaynağa göre temelde iki gruba ayrılmaktadır. Uyuşturucu maddelerin bir kısmı doğal (tabii) maddeler grubunda iken bir k1smı da sentetik maddeler grubu olarak nitelendirilmektedir. ${ }^{10}$

Geçmişten beri uyuşturucu maddelerin ağırlıklı kısmını doğal maddeler oluşturmaktadır. Doğal maddeler ise haşhaş ve kenevir gibi doğrudan bitkilerden elde edilen maddeler olarak bilinmektedir. Özellikle haşhaşın çizilmesiyle elde edilen afyon, saf halde kullanıldığı gibi afyondan da çeşitli türevler ortaya çıkarılmaktadır. Bunlar da morfin, kodein ve eroin şeklinde

Uyuşturucu maddelerin eskiden beri tıpta kullanımından dolayı birçok dilde ilâç anlamı taşıyan kelimeler aynı zamanda uyuşturucu maddeleri de ifade eder. Tuncay Başoğlu, "Uyuşturucu", DİA, C. 42, TDV Yay., İstanbul 2012, s. 248; Kültegin Ögel, Sigara, Alkol ve Madde Kullanım Bozukluklarl: Tanı, Tedavi ve Önleme, Yeniden Yayınları, İstanbul 2010, s. 3.

${ }^{6}$ World Health Organization (WHO), https://www.who.int/health-topics/drugs/ Erişim Tarihi 11/12/2019; Yılmaz Günal, Uyuşturucu Madde Suçları, Kazanc1 Yayınları, Ankara 1976, s. 7-8; Türk Dil Kurumu'na göre ise uyuşturma özelliği olan, uyuşturan, gereği gibi düşünmekten alıkoyan maddeler olarak tanımlanmaktadır. Türk Dil Kurumu (TDK), htpp://tdk.gov.tr/Erişim Tarihi 15/11/2018.

${ }^{7}$ Ögel, Sigara, Alkol..., s. 3.

${ }^{8}$ Bağımlılık yapabilen uyuşturucu maddeler içerisinde uyarıcı maddeleri de değerlendirmek gerekmektedir. Ögel, Sigara, Alkol..., s. 3, Kültegin Ögel, Bağımlılı̆̆ı Önleme Anne-Babalar Öğretmenler İçin Kılavuz, IQ Kültür Sanat Yayınlar1, İstanbul 2001, s. 3-4.

${ }^{9}$ Dünya Sağlık Örgütü’ne göre bitkisel kökenli veya sentetik olup fiziksel, ruhsal bağımlılığa yol açan ve tutku yaratan bütün maddeler uyuşturucu madde olarak kabul edilmektedir. Ayrıntılı bilgi için bkz. World Health Organization (WHO), https://www.who.int/health-topics/drugs/ Erişim Tarihi 11/12/2019; Emniyet Genel Müdürlüğü Kaçakç1lık ve Organize Suçlarla Mücadele Daire Başkanlığı, Kaçakçılık ve Organize Suç Terimleri / Kaçakçılık ve Organize Suçlarla Mücadele Rehberi V. Emniyet Genel Müdürlügü KOMDB Yayınları, Yayın No:2002/4, Ankara, 2002, s. 290.

${ }^{10}$ Ögel, Sigara, Alkol ..., s. 4; Başoğlu, a.g.m., s. 248. 
sıralanmaktadır. ${ }^{11}$ Ayrıca bu grup içerisinde değerlendirilebilecek kenevirden elde edilen esrar da doğal maddeler içerisinde önemli bir yere sahiptir. ${ }^{12}$ Tıbbî açıdan THC denilen (Tetrahidrokannabinol) bileșeni bünyesinde barındıran esrar, bu bileșenin de etkisiyle uyku verici özelliği nedeniyle geçmişten beri anestezide yaygın şekilde kullanılmaktadır. ${ }^{13}$ Diğer taraftan doğal uyușturucu maddeler içerisinde daha çok Güney Amerika'da bulunan koka bitkisinden elde edilen kokain de uyarıcı özelliğinin yanı sıra uyuşturucu özelliğiyle bu grup içerisinde değerlendirilmektedir. ${ }^{14}$

Uyușturucu madde kaynakları içerisinde ikinci bir grubu da sentetik uyușturucular oluşturmaktadır. Bunlar kimyasal yollarla laboratuvarlarda üretilmiş olan suni uyuşturuculardır. En az doğal uyușturucular kadar zararlı olan bu maddelerin tüketimi, rahatça gizlenebilmesi ve kullanım kolaylığı nedeniyle tehlikeli boyutlardadır. Doping amacıyla da kullanılan, yorgunluk hissini azaltıcı etki birakan amfetaminler ile yine kimyasal yollardan laboratuvarlarda üretilen "captagon" ve "ecstasy" en fazla bilinen sentetik uyuşturucular olarak dikkati çekmektedir. ${ }^{15}$

Uyuşturucu maddeler içerisinde gerek doğal gerek sentetik maddeler olarak ifade edilen madde türlerinin ortak özelliği, dikkatli olunmadığı takdirde bağımlılık yapmasıdır. Bu kapsamda tıbbî açıdan bağımlılık yapabilen maddeler; afyon, morfin, eroin, kodein, metadon, barbitüratlar, sedatifler, tranklizanlar, GHB, kokain, amfetaminler, metamfetaminler, captagon, ekstazi, esrar, marihuana, meskalin, LSD, ketamin gibi çeşitli türlerden oluşmaktadır. ${ }^{16}$ Bunların bir kısmı yasal olarak eczanelerde bulunabilen, hekim tarafından reçete edilen ilaç olup halen tıpta tedavi amacıyla kullanılmaktadır. Hekim tavsiyesi ile belli doz ve sürelerde kullanıldığı takdirde bağımlılık yapma olasılığının düşük olduğu ancak bu ilaçların kontrol dışı, uzun süreli ve yüksek dozlarda kullanıldığı zamanlarda bağımlılık oluşturma ihtimalinin yüksek olduğu kabul edilmektedir. ${ }^{17}$

Volume 12

İnsanlık tarihi boyunca uyuşturucu kaynağı olarak görülen bu maddeler güçlü bir ağrı kesici, acı dindirici, uyku düzenleyici, sakinleștirici, yatıștırıcı, kaygı giderici, keyif verici, uyarıcı, zihin açıcı bazı özelliklere sahip olsalar da kişiler üzerinde bazı sorunlara da sebebiyet veren maddeler olarak bilinmektedirler. Nihayetinde uyuşturucu kaynağı maddeler hem ruhsal hem de fiziksel olarak alışkanlık yapabilen, uyuşturan, yalancı neşe ve mutluluk veren, vücudun kısa sürede alışması ile ilk etkilerini kaybederek doz artırma arayışına sürüklemesi nedeniyle toplumları

${ }^{11}$ Özcan Köknel, Bă̆ımlılık (Alkol ve Madde Bă̆ımlılı̆̆l), Altın Kitaplar Yay. İstanbul 1983, s. 293; Baktır, a.g.m., s. 442; Köksal Bayraktar, "Uyuşturucu Maddeler ve Suç Siyaseti", İstanbul Üniversitesi Hukuk Fakültesi Mecmuası, C. LI, S. 1-4, 1985, s. 47; Timur Demirbaş, Kriminoloji, 2. Bask1, Seçkin Yayıncılık, Ankara 2005, s. 279-281.

${ }^{12}$ Esrar, kenevir (kendir) bitkisinden elde edilen uyuşturucu bir madde olup Türkiye'de esrar; İran'da beng/benc; Hindistan'da banga, ganja; Irak, Suriye ve Mısır'da haşiş; Kuzey Afrika'da kif; Amerika ve Meksika'da marijuana (marihuana) adlarıyla tanınmaktadır. Ayrıntılı bilgi için bkz. Turhan Baytop, "Esrar", s. 431-432; Esrar, uyuşturucu kullanıcıları arasında en yaygını olup tıbbi açıdan afyona göre öldürücülüğü daha düşük olmasına rağmen daha fazla bağımlılık yapıcı ve öldürücü özelliği bulunan uyuşturuculara geçiş anlamında basamak olarak kullanılmasindan dolayı dikkat edilmesi gereken bir maddedir. Alex Stevens, Drugs, Crime and Public Health (The Political Economy Of Drug Policy), Routledge İs An İmprint Of The Taylor \& Francis Group, New York 2011, p. 25; Sulhi Dönmezer, Kriminoloji, Beta Yayınevi, 8. Bask1, İstanbul 1994, s. 299-300.

${ }^{13}$ Sabri Sözer, Uyuşturucu Maddeler ve Problemleri, Ankara 1956, s. 39; Turhan Baytop, "Esrar", s. 431-432.

${ }^{14}$ Kokain, Amerika kıtasında uyuşturucu maddeler içerisinde en yaygın olanlardan birisi olarak dikkati çektiğinden kokain kullanımı bir halk sağlı̆̆ı problemi olarak görülmektedir. Daniel Brookoff, Elizabeth A. Campbell, Leslie M. Shaw, "The Underreporting of Cocaine-Related Trauma: Drug Abuse Warning Network Reports vs Hospital Toxicology Tests", American Journal of Public Health, Volume 83, Issue 3, p. 369; Günal, a.g.e., 26-27.

${ }^{15}$ Ögel, Sigara, Alkol..., s. 3-4; Başoğlu, a.g.m., s. 248, Demirbaş, a.g.e., s. 273.

${ }_{16}$ Özcan Köknel, Bă̆ımlılık (Alkol ve Madde Bă̆ımlılı̆̆ı), Altın Kitaplar Yay. İstanbul 1988, s. 51.

${ }^{17}$ Ögel, Sigara, Alkol..., s. 4. 
etkilemişlerdir. ${ }^{18}$ Çeşitli türdeki bu maddeler, diğer toplumlarda olduğu gibi doğal olarak Osmanlı toplumsal hayatında da farklı alanlardaki etkisiyle dikkati çekmişlerdir.

\section{Osmanlı Döneminde Uyuşturucu Madde Kaynakları}

Osmanlı ekonomik ve toplumsal hayatı bilindiği gibi diğer Türk-İslâm medeniyetlerinin devamı niteliğindeki yapısıyla dikkati çekmiş olup bu devamlılığın bir parçası da geçmişten devraldığı tıbbî tedavi yöntemleri ve tedavide kullanılan bazı bitkilere yönelik tüketim alışkanlıklarıdır. Nitekim bu amaca hizmet eden haşhaş ve kenevir bitkisi, Osmanlı sosyoekonomik hayatında tedavide önemli bir yere sahip olmuş, geçmiş medeniyetlerde olduğu gibi uyuşturucu maddelerin de temel kaynağını teşkil etmiştir.

Tarihsel süreçte haşhaş ve kenevir bitkisi farklı kullanım alanları olan tarım ürünleri olarak dikkati çekmişlerdir. Bu bitkiler gıda, giyim ve sağlık gibi farklı sektörlerde kullanım alanına sahip olduğundan geçmişten beri talep gören ürünler olarak varlık göstermiştir. Bunlar içerisinde özellikle haşhaştan elde edilen afyon, eski uygarlıklarda olduğu gibi Türk-İ̀lâm toplumlarında da hekimlerin sağlık alanında kontrollü şekilde uygulanmasına cevaz verdiği ürünler arasında önemli bir yere sahiptir. ${ }^{19}$

Geçmişten beri sağlık alanında kontrollü şekilde uygulanmasına izin verilen başka bir bitkiyi de kenevirden üretilen esrar oluşturmaktadır. ${ }^{20}$ Sağlık alanında uyku verici ve anestetik özellikleri nedeniyle bilinen esrara hem İslâm toplumunda hem de Avrupa'da müracaat edilmiş, bunun yanı sıra XIII ve XIV. yüzyıllarda esrarotu, afyon, adamotu ve banotunun karışımından hazırlanmış "spongia somnifera" adlı preparata da yine cerrahi anestezide başvurulmuştu. ${ }^{21}$

Eski toplumlarda kullanıldığı gibi Osmanlı toplumunda da yaygın şekilde "beng"22 adıyla zikredilen esrar; sıtma, romatizmanın, gut gibi hastalıkların tedavisinin yanı sıra çeşitli rahatsızlıklarda ağn kesici işlevi görmüş, özellikle mide ile bağırsak ağrıları ile yarım baş ağrılarını gidermek için sıklıkla müracaat edilmiştir. ${ }^{23}$ Yine Osmanlı toplumunda esrarın yanı sıra amber, tarçın, safran gibi aromatik maddelerle afyonun karıştırılması suretiyle de ağrı kesici ilaçlar elde edilmeye çalışılmıştır. Bundan dolayı afyon, Osmanlılar döneminde en çok müracaat edilen ağn kesici olarak kendini hissettirmiş, tedavide ise tentür veya ekstre halinde yaygın şekilde kullanılmıştır. ${ }^{24} \mathrm{Bu}$ kapsamda XIV. yüzyıldan itibaren yazılmış tıp eserlerinde tedavi edici özellikleri nedeniyle afyondan sıkça söz edilmektedir. Hatta bir tür afyonlu macun olan "berş" maddesinin sindirim sistemine (özellikle yemek hazım sorunu ve mide rahatsızlıklarına),

\footnotetext{
${ }^{18}$ Köknel, a.g.e., s. 51; Celalettin Vatandaş, Türkiye'de Gençlik ve Uyuşturucu Madde Sorunu, Sosyal, Ekonomik ve Kültürel Araştırmalar Merkezi (SEKAM) Yay., İstanbul 2015, s. 17-23.

${ }^{19}$ Ağırakça, a.g.m., s. 142-144; Hamarneh, a.g.m., p. 230-231.

${ }^{20}$ Sözer, a.g.e., s. 39; Turhan Baytop, "Esrar", s. 431-432.

${ }^{21}$ Ortaçağ İslâm toplumunda esrara tıbbî amaçlarla yoğun bir şekilde müracaat edilmektedir. Örneğin İbni Sina, "Kanun" adlı eserinde afyonun yanı sıra esrarotunun yapımı ve kullanımından söz etmektedir. Bkz. Ayşegül Demirhan, Geçmişte ve Günümüzde Esrar, İstanbul Üniversitesi İstanbul Tıp Fakültesi Yay. 1979, s. 37.

22 "Beng", birçok kaynakta afyon gibi uyuşturucu ve keyif verici "ban" denilen yapraklı bir nebat ve bunun tohumu olarak zikredilmektedir. Ferit Develioğlu, Osmanlıca Türkçe Ansiklopedik Lûgat, Aydın Kitabevi, 30. Baskı, Ankara 2013, s. 107; Gelibolulu Mustafa Âli, Mevâidü’n-Nefâis Fî Kavâidi'l Mecâlis II (Görgü ve Toplum Kuralları Üzerinde Ziyâfet Sofraları), haz. Orhan Şaik Gökyay, Tercüman 1001 Temel Eser, İstanbul 1978, s. 326; Bununla birlikte beng'in sadece ban otunu ifade etmediği, belli çevrelerde veya bazı dönemlerde bununla Hint keneviri ve diğer bitkilerden çıkarılan uyuşturucuların da kastedildiği anlaşılmaktadır. Nitekim Fuzûlî’nin Beng ü Bâde adlı eserinde beng "esrar" anlamında kullanılmakta ve Osmanlı kaynaklarında bu kavram daha çok esrarı ifade etmek tedir. Başoğlu, a.g.m., s. 249.

${ }^{23}$ Ali Nahit Babaoğlu, Uyuşturucu ve Tarihi, Kaynak Yayınları, İstanbul 1997, s. 83; Turhan Baytop, "Esrar", s. 431. ${ }^{24}$ Mat, a.g.m., s. 285-286.
} 
boşaltım sistemine ve bel ağrılarına fayda sağladığı belirtiliyordu ${ }^{25}$ Bilhassa afyon ve afyon karışımları, toplumun geneli tarafından benimsenerek anestetik amaçlarla çeşitli ağrının, sızının tedavisinde ve öksürük gibi rahatsızlıklarda yumuşatıcı vazifesi görüyor, sadece halk arasında değil, saray hekimlerince de yaygın şekilde kullanılıyordu. ${ }^{26}$

Osmanlı Klasik Dönemi'nde afyona ve esrara sağlık alanında müracaat edilmesi arzulanıyordu. Ancak Osmanlı toplumunda geleneksel usullerle imal edilen afyon, afyon macunları ve şurupları ile esrar türevi ürünler, zengin uyuşturucu içeriğine sahip oldukları için tedavi amacı dışında keyif verici bir madde olarak da kullanılıyordu. ${ }^{27} \mathrm{Bu}$ maddeler, gayri resmi şekilde keyif amacıyla kullanılmış olsa da özellikle devlet tarafından sağlık amacı doğrultusunda kullanılmasının özendirilmesi dikkati çekmektedir.

Osmanlı toplumunda afyon başta olmak üzere esrar maddesinin sağlık alanında belirgin bir şekilde önem kazanması, XIX. yüzyılın başlarına tekabül etmektedir. Bu dönemde sanayileşme ve buna bağlı gelişen ilaç sanayisindeki gelişmeler morfin, eroin ve esrar gibi maddelerin Avrupa'da tedavide uyuşturucu ve ağrı kesici olarak talep görmesini sağlamıştır. ${ }^{28}$ İlk olarak XIX. yüzyılın başlarında 1804 yıllında morfinin bulunması, ${ }^{29}$ daha sonra 1832 yılında morfinden hareketle kodeini izole edilmesine imkân sağlamıştır. ${ }^{30}$ Nihayetinde ilaç ve eczacılık alanında meydana gelen gelişmelerle birlikte XIX. Yüzyılın ikinci yarısında afyonun kimyasal özelliklerinden hareketle morfinin sentezlenmesiyle birlikte yeni bir ürün olarak eroinde seri üretime geçilmesi, afyonun sınaî bir ürün olarak değer kazanmasını sağlamıştır. ${ }^{31}$ Ağırlıklı olarak Osmanlı topraklarında üretilen afyonun ilaç firmalarına ait laboratuvarlarda morfinin asetik asit, yani sirke asidiyle etkileşimiyle geliştirilen eroin, ilaç piyasasında önemli bir pazar elde etmeye başlamış ve kısa süre içerisinde İngiltere başta olmak üzere Avrupa'nın diğer ülkelerinde ve dünya genelinde yaygınlık kazanmıştı. Ancak eroinin çeşitli faydalarına rağmen insan sağlığı üzerinde özellikle bağımlılık yapıcı etkileri, toplum sağlığını da beraberinde etkilemiştir. ${ }^{32}$

Osmanlı Klasik Dönemi'nden itibaren uyuşturucu madde kaynağı olan haşhaş ve kenevir bitkilerinin her bir dönemin özelliklerine göre farklı içeriklerde üretim sürecine dâhil edilmesi, aslında bu bitkilerden ekonomik ve sosyal hayatta vazgeçilemez olduğunu da göstermektedir. Bundan dolayı Osmanlılarda gerek haşhaş gerekse kenevir bitkileri için belli bir arz ve talep piyasası da süreç içerisinde ortaya çıkmıştır.

\footnotetext{
${ }^{25}$ Murat Uluskan, “İstanbul'da Bir Afyonlu Macun İşletmesi: Berş-i Rahîkî Macunhanesi (1783-1831)”, Türk Kültürü̈ Incelemeleri Dergisi, S. 29, İstanbul 2013, s. 80.

${ }^{26}$ Mossensohn, a.g.e., p. 39-40.

${ }^{27}$ Evliyâ Çelebi Seyahatnâmesi II. Kitap, s. 607-608; Amasyan Efendi, Afyon Tohumu Ziraatı Layihası, La Türki Matbaası, İstanbul 1287, s. 3; Ali Haydar, Haşhaş Ziraatı, Matbaa-1 Osmaniyye, Dersaadet 1330, s. 5, Turhan Baytop, "Eczacilik", s. 387.

${ }^{28}$ Wolfgang Schivelbusch, Keyif Verici Maddelerin Tarihi, Çev. Zehra Aksu Yılmazer, Genesis Kitap Yayınları, Ankara 2012, s. 215, 219; Babaoğlu, a.g.e., s. 211.

${ }^{29}$ Martin Booth, Haşhaştan Eroine Uyuşturucunun 6000 Yıllık Öyküsü, Sabah Kitapları, İstanbul 1996, s. 60.

${ }^{30}$ Köknel, a.g.e., s. 293; Nuran Taşlıgil ve Güven Şahin, "Tarihsel Süreçte Haşhaş ve Afyon", Tarih Okulu Dergisi, S. XXXIV, Haziran 2018, s. 176.

31 XIX. yüzyılda elde edilen uyuşturucu maddeler içerisinde en önemlilerinden birisi de eroindir. Yarı sentetik bir madde olarak eroin ilk olarak 1874 yılında Londra'da morfinin kimyasal özelliklerinin dönüştürülmesiyle elde edilmiş ve daha sonra da Almanya'da seri üretim aşamasına geçilmişti. Ayrıntılı bilgi için bkz. Louise Foxcroft, The Making of Addiction (The 'Use and Abuse' of Opium in Nineteenth-Century Britain), Published by Ashgate, England 2007, p. 10; F. Cengiz Erdinç, Overdose Türkiye, İletişim Yayınları, İstanbul 2004, s. 24-25.

${ }^{32}$ Schivelbusch, a.g.e., s. 215, 219; Babaoğlu, a.g.e, s. 54-55; Toby Seddon, "The Regulation of Heroin: Drug Policy And Social Change İn Early Twentieth-Century Britain”, International Journal Of The Sociology Of Law, Volume 35, Issue 3, September 2007, p. 143-144; Taşlıgil ve Şahin, a.g.m., s. 168,176.
} 
Osmanlı Sosyoekonomik Hayatında Uyuşturucu Madde Kaynaklarının Arz Boyutu...

\section{Osmanlı Döneminde Uyuşturucu Madde Kaynaklarından Haşhaş ve Kenevir Bitkisinin Arz Boyutu}

Tarih boyunca uyuşturucu maddeler, üretimden başlayarak tüketime varıncaya kadar kendine uygun bir arz ve talep sistemi ortaya koymuştur. Bu sistem içerisinde her bir dönemde uyuş̧turucu maddenin adı değişse de uyuşturucu maddelerin hammaddesini oluşturan ziraî ürünler değişmemiş ve uyuşturucu maddenin hammaddesini oluşturan zirai ürünler içerisinde en başta gelenleri ise haşhaş ve kenevir bitkileri oluşturmuştur.

Eski toplumların genelinde olduğu gibi Osmanlı toplumunda da keyif verici özellikleri nedeniyle yaygın olmasa da belli bir kullanıma konu olan uyuşturucu maddeler içerisindeki afyon ve esrarın kaynağı olan haşhaş ve kenevir bitkisi, Osmanlı ziraî hayatında ekonomik bir işleve sahip olmuştur. Özellikle gelir getirici ziraî bir ürün olarak haşhaş bitkisi, ekonomik ve toplumsal hayatta önemli bir pozisyon elde etmiştir.

\subsection{Osmanlı Ziraî Ekonomisinde Haşhaş ve Kenevir Bitkisi}

\subsubsection{Haşhaş Bitkisi ve Osmanlı Döneminde Haşhaş Ekimi}

Haşhaş bitkisi, M.Ö. 5000 yıllarından beri ziraatı yapılan bir ürün olarak bilinmektedir. 30$200 \mathrm{~cm}$. boyunda bir y1llık otsu bir bitki olan haşhaş, uzun yıllardır Anadolu topraklarında yetiştirilen ve çok çeşitli şekillerde istifade edilen özel bir tarım ürünü olarak dikkati çekmektedir. Özellikle bu bitkiden elde edilen haşhaş tohumu ve tohumdan elde edilen haşhaş yağı ile ezmesi, faydalı gıda maddeleri arasında yer almıştır. ${ }^{33}$

Tarih boyunca farklı coğrafyalarda ziraatı yapılan haşhaş bitkisi ve bu bitkiden elde edilen afyon, zaman içerisinde kendine ait bir ekonomik yapı inşa etmiş, Osmanlı Devleti de bu yapıdan kendine düşen payı almıştır. Bir kente adını verebilecek kadar Anadolu coğrafyasında izler bırakmış olan afyon, Osmanlı Devleti için gerek sağlık gerekse ekonomik açıdan önemli bir faaliyet alanı olmuş, en dikkat çekici ihraç mallarından birisi olarak varlığını muhafaza etmiştir. ${ }^{34}$ Diğer taraftan Anadolu'da haşhaş yetiştiriciliği ve elde edilen afyon, ekonomik ve sosyal hayatta geniş bir yer tutmuş, ayrıca devlet açısından gelir kaynağı vazifesi görmüştür. Bu kapsamda tahrir defterlerindeki "öşrr-i afyon" adıyla toplanan vergi, XVI. yüzyıl içerisinde altı kat artarak hazineye önemli miktarda gelir sağlamıştır. ${ }^{35}$ Devletin afyonda elde ettiği öşür geliri sadece bu dönem için geçerli olmayıp, XIX. yüzyılda dahi vazgeçemediği gelirler arasında yer almıştır. ${ }^{36}$ Yine bunun yanı sıra devlet, sadece öşr-i afyon vergisi almakla sınırlı kalmayarak öşr-i afyon aldıktan sonra haşhaşın gida maddesi olarak kullanılması durumunda da öşür vergisi alınabileceğini kabul ederek, haşhaş ve afyonu dikkate değer bir gelir kalemi olarak kabul etmiştir. ${ }^{37}$

Osmanlılar Döneminde haşhaş, Anadolu'da yaygın bir şekilde yetiştirilmiş, özellikle Batı Anadolu, afyon üretim merkezi olmuştur. Hatta burada yer alan ve eski adı Karahisar-1 Devle veya Karahisar-1 Sahib olan şehrin ad1, XVI. yüzyıldan itibaren haşhaş üretiminin artmasına

\footnotetext{
${ }^{33}$ Turhan Baytop, "Haşhaş", DİA, C. 16, TDV Yay., İstanbul 1997, s. 403; Taşlıgil ve Şahin, a.g.m., s. 163-164.

${ }^{34}$ Burak Çıtır, "Uluslararası Afyon Anlaşmalarında Osmanlı İmparatorluğu", Sosyal ve Kültürel Araştırmalar Dergisi, C. I, S.1, 2015, s. 24, 35.

${ }^{35}$ Taşlıgil ve Şahin, a.g.m., s. 174-175.

${ }^{36}$ Devlet Arşivleri Başkanlığı Osmanlı Arşivi (BOA), Maliyeden Müdevver Defter (MAD.d), nr. 8312, 29/12/1835 (9/N/1251); BOA, MAD.d, nr. 9674, 11/03/1839 (25/Z/1254).

37 "Soru: Zeyd tarlasında haşhaş ekip bitip afyondan sâhib-i arz öşrünü aldıkdan sonra haşhaşından dahi öşür almağa kâdir olur mu? el-Cevâb: Olur” bkz. Abdulkadir Atar, Şeyhülislam Fetvaları Işı̆̆ı̆nda Osmanlı’da İktisadi Hayat, Albaraka Yay., İstanbul 2020, s. 221.
} 
paralel olarak afyon üretim merkezi haline gelmesi nedeniyle XVII. yüzyılda Afyonkarahisar adını almıştır. ${ }^{38}$

Osmanlı Döneminde Afyonkarahisar başta olmak üzere diğer Anadolu şehirlerinde haşhaş ekiminin ve haşhaştan elde edilen afyon üretiminin arttığı asıl dönem XIX. yüzyıldır. Bu yüzyılda özellikle Abdülhamit döneminde bir tarım ve maliye politikası olarak afyon üretiminin teşvik edilmesi dikkat çekicidir. Teşvik kapsamında öne çıkan uygulamaların başında, Anadolu'da afyon ekim alanının genişletilmesi için çiftçilerin afyon ekimine özendirilmesi ile bir yıldan üç yıla kadar vergi muafiyetleri gelmişti. ${ }^{39}$ Ancak bu dönemde devlet, haşhaş ekimini teşvik etmeye çalışsa da dünyada afyonun kısıtlanmasına yönelik politikalar, XX. yüzyılın başlarında Osmanlı'da haşhaş üreticisini ve ekimini olumsuz etkilediğinden üretimde düşüşler meydana gelmeye başlamıştır. Bu durum aşağıdaki tablo ve grafikte rahatlıkla görülebilmektedir.

Tablo: 1 Osmanlı Son Döneminde Afyon Üretim Durumu (1875-1923)

\begin{tabular}{|l|l|l|l|}
\hline Y1l & Miktar (Sand1k)* & Y1 & Miktar (Sandik) \\
\hline 1875 & 3.600 & 1905 & 2.900 \\
\hline 1880 & 2.800 & 1910 & 7.000 \\
\hline 1885 & 7.000 & 1915 & 3.800 \\
\hline 1890 & 6.000 & 1920 & 3.700 \\
\hline 1895 & 8.300 & 1922 & 3.500 \\
\hline 1900 & 8.500 & 1923 & 2.200 \\
\hline
\end{tabular}

Kaynak: Filiz Çolak, “Anadolu'da Afyon Ziraati ve Ticaretine Dair İzlenimler”, The Journal of Academic Social Science Studies, V. 6/1, January 2013, s. 524; Şevket Pamuk, 19. Yüzyılda Osmanlı Dış Ticareti, Ankara 1995, s. 42.

* Osmanlı Devleti'nde afyonda ölçü birimi olarak sandık kullanılmakta olup 1 sandık afyon 60 okkaya, 1 okka da 1,282 kilograma denk geldiğinden 1 sandık afyonun ağırlığ 76,92 kilograma tekabül etmektedir. Ayrıntılı bilgi için bkz. Şevket Pamuk, "Money İn The Ottoman Empire 1326-1914”, An Economic and Social History of the Ottoman Empire 1300-1914, Ed. Halil İnalc1k ve Donald Quataert, Cambridge Univ. Press, 1996, s. 992.

\footnotetext{
${ }^{38}$ Üçler Bulduk, XVI. Asırda Karahisar-ı Sahib Sancă̆ , (Yayınlanmamış Doktora Tezi, Ankara Üniversitesi Sosyal Bilimler Enstitüsü, Ankara 1993), s. 272-274; XVII. Yüzy1lda bütün Anadolu'yu gezen Evliya Çelebi, Afyon şehrine de uğramış, eserinde geniş haşhaş tarlalarından bahsetmiştir. Evliya Çelebi, Seyahatnâme, IX. Kitap, haz. Yücel Dağlı, Seyit Ali Kahraman ve Robert Dankoff, Yapı Kredi Yayınları, İstanbul 2005, s. 21.

${ }^{39}$ Donald Quataert, Anadolu'da Osmanlı Reformu ve Tarımı (1876-1908), çev. Nilay Özok Gündoğan ve Azat Zana Gündoğan, Türkiye İş Bankası Kültür Yayınları, 2008, s. 244; Afyon üreticilerine sağlanan teşvik ve kolaylıklar içerisinde çoğunlukla birer yıllık öşür vergisi muafiyeti uygulanıyordu bkz. Devlet Arşivleri Başkanlığı Osmanlı Arşivleri (BOA), Dahili Mektûbat (DH.MKT), nr. 2370/7, 10/03/1901 (19/ZA/1318); Hasıl olan afyon ve haşhaş tohumlarından devletin sekizde bir oranında öşür vergisi aldığı görülmekteydi. BOA, Hazine-i Hâssa Nezâreti Defterleri (HH.d), nr. 24838, 08/01/1841(07/ZA/1256).
} 
Grafik: 1 Osmanlı Son Döneminde Afyon Üretim Miktarının Yıllara Göre Değişimi (18751923) Miktar Sandık Cinsinden

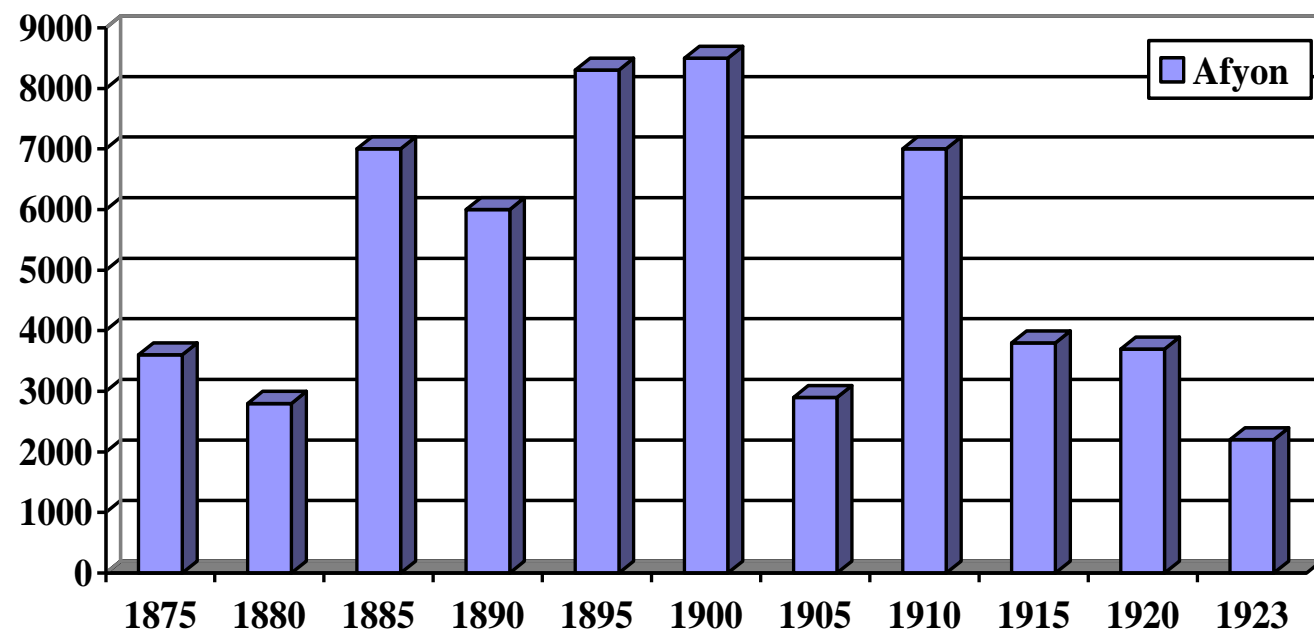

Tablo1 ve Grafik 1 birlikte değerlendirildiğinde 1880'li yılların ortalarından itibaren özellikle 1885-1900 arasında uygulanan teşvik politikalarının da etkisiyle afyon üretim miktarında gözle görülür bir artış kaydedilmektedir. Ancak XX. yüzyılda gelindiğinde bazı yıllar istisna tutulursa gerek dünya afyon piyasasında yaşanan daralmalar gerekse de ülkenin içinde bulunduğu savaş koşullarının ağırlaşması, afyon üretiminde düşüşler yaşanmasıyla sonuçlanmıştır. Netice olarak Osmanlı Devleti'nin son elli yıllık süreci dikkate alındığında, afyon üretim miktarının bu dönem içerisinde dalgalı bir seyir izlediği görülmektedir.

\subsubsection{Kenevir Bitkisi ve Osmanlı Döneminde Kenevir Ekimi}

Kenevir bitkisi, haşhaş bitkisi gibi tarihi bir geçmişe sahiptir. Mezopotamya'da Sümerlerden itibaren tanınan ve tohumları ilaç olarak kullanılan kenevirin Avrupa'ya milattan önce VII. yüzyılda İskitler tarafından taşındığı sanılmaktadır. Bunun yanı sıra uyuşturucu madde olarak kullanılışına ait ilk bilgiler ise Herodot Tarihi'ne (M.Ö. V. Yüzyıl) kadar dayanmaktadır. ${ }^{40}$

Uzakdoğu'dan batıya kadar geniş bir alanda ekilen kenevir bitkisi, Anadolu topraklarında geçmişten beri bilinen bir ürün olarak dikkati çekmektedir. Bu ürün, biçim özellikleri itibarıyla yetiştiği bölgelere ve kimyasal özelliklerine göre lif keneviri ve Hint keneviri olarak başlıca iki türe ayrılmaktadır. Lif keneviri (cannabis sativa), Kuzey Avrupa ve Amerika ülkelerinde geniş ölçüde yetiştirilen bir ürün olup bu ürünün uyuşturucu etkisi zayıftır ve genellikle lif ve tohum elde etmek üzere kullanılmaktadır. Hint keneviri (cannabis indica) ise bilhassa Güney Asya, Afrika, Orta ve Güney Amerika'da yetiştirilmektedir. Uyuşturucu etkisi yüksek olduğundan esrar bu türden elde edilmektedir. ${ }^{41}$

İki tür kenevir içerisinde Osmanlı sosyoekonomik hayatında daha çok tekstil ile dokumacılık alanındaki kullanımıyla "kettan, kendir, kendir lifi, kendir teli, tel kendir" ismiyle zikredilen "lif keneviri" geniş bir kullanım alanına sahipti. Bu kenevir türü başta sicim, ip, urgan ve kumaş

${ }^{40}$ Turhan Baytop, "Esrar", s. 431-432.

${ }^{41}$ Baytop, "Esrar", s. 431-432. 
imalatının önemli hammaddesiydi. ${ }^{42}$ Bundan dolayı Osmanlı donanmasının ihtiyacı olan urgan, halat gibi malzemelerin çoğu kenevirin sapındaki lifin çıkarılmasıyla elde edilen kendirden yapılmaktaydı. ${ }^{43}$ Ayrıca askerî sahada olduğu gibi sivil hayatta da özellikle çuval ile kaba bez üretiminde yoğun olarak kullanıldığı için Osmanlılarda başta Karadeniz Bölgesi olmak üzere Anadolu'nun geniş coğrafyas ${ }^{44}$ ile Balkanlarda ekilen ziraî ürünler içerisinde kenevir bitkisi kendine rahatlıkla yer buluyordu. ${ }^{45} \mathrm{Bu}$ duruma örmek teşkil etmesi açısından XVI. yüzyılın ikinci yarısında Konya ve çevresinde toplam tarımsal üretim incelendiğinde, bunun \%1'inin kenevir ve keten üretiminden meydana geldiği görülmekteydi. ${ }^{46}$ Yine XVI. yüzyılda Karahisar-1 Sahib Sancağı'nın (Afyon) önemli gelir kaynakları arasında kenevir ve keten üretimi dikkat çekiyordu. ${ }^{47}$ Ayrıca İzmit, Bursa ve Musul civarı üretim miktarı ve kalite açısından önde gelen bölgeler arasında yer aliyordu. ${ }^{48}$

Osmanlı ekonomik hayatında tekstil ve dokumacılık alanındaki kullanımından dolayı zirai üretimde kendine yer bulan kenevir ve keten bitkisi, yetkili makamlarca teşvik ediliyordu. Ayrıca bu teşvikin kapsamı kenevire dayalı imalat sanayiinde hizmet eden işletme sahipleri için de geçerliydi ve bu işletme sahiplerine vergi muafiyeti sağlanması, en başta gelen kolaylıklar arasinda yer aliyordu. ${ }^{49}$

Kenevir bitkisinin teşvik edilmesi ve tarihsel süreç içerisinde önem kazanmasında en önemli faktörlerden birisi de bu bitkinin tıbbî amaçlarla kullanılmasıydı. Aynı şekilde Osmanlı toplumunda da kenevir bitkisinin afyon bitkisi gibi sağlık alanında uyuşturucu olarak kullanımının artması da devlet tarafından üretimin teşvik edilmesine yol açmıştır. Ancak kenevirin bu faydalarına rağmen kenevirden elde edilen esrarın geçmişten beri keyif amacıyla kullanımı, kenevir üretimine karşı ilgili birimlerin dikkatli davranması gerektiğini ortaya koymuştu.

Volume 12 Issue 6

December 2020

\subsection{Haşhaş ve Kenevir Bitkisinden Afyon ve Esrar İmal Edilmesi}

Haşhaş ve kenevir bitkileri farklı kullanım alanları olan tarım ürünleri olarak dikkati çekmişlerdir. Bu bitkiler gıda, giyim ve sağlık gibi farklı sektörlerde kullanım alanına sahip olduğundan geçmişten beri talep gören ürünler olarak varlık göstermiştir. Bunlar içerisinde özellikle haşhaştan elde edilen afyon, sağlık alanının vazgeçilmez bir ürünü olarak ön plana çıktığından haşhaş tarımı dünyanın birçok yerinde çok eski tarihlere dayanmaktadır. ${ }^{50}$ Ayrıca

\footnotetext{
${ }^{42}$ Keten ile kendir arasında bazı farklar bulunmaktadır. Keten daha çok yazlık türü elbiselik kumaşlarda kullanılırken, kendir ise daha çok kaba dokunan çadır, branda, kalın kumaş, ip, urgan, halat gibi malzemelerin yapımında kullanılmaktaydı. Ayrıntılı bilgi için bkz. Mehmet Taşdemir, "Karadeniz Bölgesinde Kendir-Keten Üretimi ve Kullanım Alanları", Türk Kültürü İncelemeleri Dergisi, Sayı 8, İstanbul 2003, s. 3-5.

${ }^{43}$ İdris Bostan, Osmanlı Bahriye Teşkilâtı: XVII. Yüzyılda Tersâne-i Amire, Türk Tarih Kurumu Yayınları, Ankara 1992, 137; BOA, Ali Emiri Selim (AE.SSLM.III), nr, 4731, 29/12/1799 (01/Ş/1214).

${ }^{44}$ Taşdemir, a.g.m., s. 1-24.

${ }^{45}$ Niş'in Lefkofça Kazasında bolca yetiştirilen kenevirden elde edilen dokuma numunelerinin Seraskerlik makamına takdimi hakkında bkz. BOA, Sadaret Mektubî Kalemi (A.MKT), nr. 28/57, 27/09/1845 (25/N/1261).

${ }^{46}$ Suraiya Faroqhi, Osmanlı'da Kentler ve Kentliler, Çev. Neyyir Kalaycıŏlu, Tarih Vakfı Yurt Yayınları, İstanbul 2000, s. 391-395.

${ }^{47}$ Bulduk, a.g.t., s. $273-274$.

${ }^{48}$ Esrarın etkili maddesi, kenevir bitkisinin çiçek durumları ve genç yapraklarında bulunan tüylerin taşıdığı reçinemsi madde içinde bulunmaktadır. Reçine miktarı Hindistan kökenli kenevirlerde \%10-20 arasındadır. Türkiye'de yetişen kenevirlerin de ortalama \%10 reçine taşıdıkları tespit edilmesine karşı Avrupa ülkelerinde bu oran ancak \%5 (bazen \% 1-2) seviyesindedir. Turhan Baytop, "Esrar", s. 432.

${ }^{49}$ Selanik’te kenevir dokumasına mahsus imalathane için gerekli alet ve edevatın gümrük vergisinden muaf tutulması bu duruma örnek teşkil etmektedir. BOA, Irade Rüsumat (I.RSM), nr. 32/36, 11/11/1908 (16/L/1326).

${ }^{50}$ Kürçay, a.g.e., s. 7-8.
} 
afyon, insanlığın ilk dönemlerinden itibaren tedavi süreçlerinde müracaat edilen bir madde olmakla birlikte afyonun keyif verici biçimde kullanımının artması, bu kitleye yönelik afyon imalatında da artış yaşanmasına sebebiyet vermiştir. ${ }^{51}$

Dünyada köklü bir geçmişe sahip haşhaş bitkisi ve bunda elde edilen afyon, belli iklim koşullarında ve aşamalardan meydana gelmektedir. Bu noktada ekim mevsimi, iklim koşulları, ekim şekli, ekilen haşhaş türü ve haşhaşın bakımı gibi birçok faktör elde edilen afyon hâsılatı üzerinde belirleyici rol oynamaktadır. ${ }^{52}$ Ayrıca afyon, dikkat ve özen gerektiren bir ziraî ürün olarak bilindiğinden özellikle üretim kaybı yaşanmaması için haşhaşın çizimi ve toplanması da ekimi kadar dikkat gerektiren işler arasında yer almaktadır. Bu doğrultuda ilkbaharda haşhaş kapsülleri tam olgunlaşmadan önce özel bir çizgi bıçağı ile yatay olarak çizilmekte ve çizgi işi sabah erken saatte yapılmaktadır. Akan süt, akşamüzeri özel algı bıçağı ile toplanmakta ve bir araya getirilen ham afyon el ile yoğrularak, güneşte kurutularak topak haline getirilmektedir. ${ }^{53}$ Topak haline getirilen afyon parçaları ise genellikle kendi haşhaş yapraklarına sarılıp sandıklara konulduktan sonra, özel yerlerde istiflenmektedir. ${ }^{54}$

Haşhaşın baş kısmının çizilmesiyle ortaya çıkan ve kısa sürede katılaşan sütün toplanıp yoğrulmasıyla elde edilen ve özel yerlerde istiflenen afyondan, eski toplumlarda olduğu gibi Osmanlı toplumunda da farklı karışımlar yapılmaya çalışılmıştı. Bunların başında amber, tarçın, safran gibi aromatik maddelerle afyonun karıştırılması suretiyle ağrı kesici ilaçların elde edilmesiydi. ${ }^{55}$ Diğer taraftan ağrı kesici özelliği yanında sindirim sistemine de fayda sağladığı düşünülen ve afyondan başka biber, zencefil, tarçın, köknar, Hindistan cevizi, zerdeçöp, papatya kökü, papatya çiçeği, kızıl üzüm ve kara üzüm gibi bileşimlerin karıştırılması suretiyle de macunlar meydana getirilmişti. ${ }^{56}$ "Berş" adıyla da bilinen ve macunlar, günlük hayatta şifa amacına yönelik olanak imal edilir ve tüketilirdi. ${ }^{57} \mathrm{Bu}$ macunlar içerisinde "Berş-i Râhîkî" adıyla anılan ve afyon ile şarap türevlerinin karışımları sonucu elde edilen Rahîkî macunu, XVI. yüzyıldan itibaren şifa ve ilaç maksadına yönelik olarak üretilmeye başlamışt. ${ }^{58}$ Ayrıca Osmanlı toplumunda günlük hayatta çocukları uyutmak için hazırlanan çocuk macunları da afyon ile yapılırd1. ${ }^{59}$ Yine bu devirlerde çocuklara kolayca uyumaları için afyon katkılı şuruplar imal edilirdi. İmal edilen bu şuruplar, toplumun geneli tarafindan rahatlıkla temin edilebilirdi. ${ }^{60}$

Osmanlı toplumunda geleneksel usullerle imal edilen afyon, afyon macunları ve şurupları, zengin uyuşturucu içeriğine sahipti. Bundan dolayı haşhaştan maksimum düzeyde afyon elde

\footnotetext{
${ }^{51}$ Schivelbusch, a.g.e., s. 210-212.

${ }^{52}$ Rıza Doğukan, “Türkiye’de Haşhaş Ziraatı ve Afyon İstihsali”, Ziraat Dergisi, S. 97, 1949, s. 37-38.

${ }^{53}$ Mat, a.g.m., s. 287; Haşhaşın afyon haline getirilmesinde çizme usulü verimi doğrudan etkilediği için Osmanlı zamanında bıçakla kesim ve çizim usulü en ince ayrıntısına kadar öğretilmektedir. Bkz. Ali Haydar, a.g.e., s. 7; Amasyan Efendi, a.g.e., s. 6.

${ }^{54}$ Turhan Baytop, "Haşhaş", s. 403.

${ }^{55}$ Mat, a.g.m., s. 286; Turhan Baytop, "Haşhaş", s. 403.

${ }^{56}$ Ayşegül Demirhan Erdemir, Afyon ve Tıbbi Etik (Ve Diğer Bă̆ımlılık Yapan Maddeler), Bursa 1996, s. 18-19.

57 "Berşs", Osmanlı'da afyon şurubu ve keten yaprağı ile yapılan bir çeşit müsekkir macun olarak bilinmektedir. Ayrıntılı bilgi için bkz. Develioğlu, a.g.e., s. 115; Osmanlı'da şahısların veya vakıfların dâhil olduğu afyonlu macun (berş) imalathaneleri, morfin ve eroinin henüz imal edilmediği XIX. yüzyıl öncesinde önemli sayılabilecek derecede ticari faaliyetlerde bulunuyor ve bu ticari faaliyetler karşıllı̆̆nda devlet de vergiler yoluyla gelir elde edebiliyordu. Bkz. BOA, Cevdet Evkaf (C.EV), nr. 626/31551, 12/01/1784 (18/S/1198); BOA, Cevdet Maliye (C.ML), nr. 180/7611, 07/01/1806 (26/L/1220); BOA, C.ML, nr. 253/10464, 23/07/1810 (20/C/1225).

${ }^{58}$ Uluskan, a.g.m., s. 81-82.

${ }^{59}$ Mat, a.g.m., s. 286; Mossensohn, a.g.e., p. 40.

${ }^{60}$ Schivelbusch, a.g.e., s. 211.
} 
etmek eski medeniyetlerde olduğu gibi Osmanlı zirâi hayatında da önemsenen bir mesele olduğundan, haşhaş ekimi ve kaliteli afyon imali ile ilgili layihalar bile hazırlanmışt. ${ }^{61}$

Osmanlı Devleti'nde ve Avrupa'da afyonun kimyasal özellikleri belli ölçülerde bilinmekle birlikte afyonun zengin kimyasal özelliklerinin fark edildiği asıl dönem XIX. yüzyıldır. Tıbbî ve zengin farmakolojik özelliklerinden dolayı kimyagerler ve doktorların her zaman ilgisini çeken afyonun insan sağlığı için daha da etkin bir şekilde kullanılması adına çok sayıda araştırma yapılmıştır. Bunlar içerisinde belki de en çığır açıcı olanı 1804 yılında Alman araştırmacı Friedrich Wilhelm Sertürner tarafindan morfinin bulunmasıdır. ${ }^{62}$ Bundan sonraki süreçte gerek dünyada gerekse Osmanlı'da afyona talep artmış ve afyon, uluslararası ticaretin konusu haline gelmiştir. ${ }^{63}$ XIX. Yüzyılda morfinin askeri ve sivil hayata yönelik olarak üretiminin artması, bu maddeden hareketle yeni kimyasalların denenmesinin önünü açmıştır. Bu doğrultuda 1832 yılında Pierre Jean Robiquet, morfinden hareketle kodeini izole etmiştir. ${ }^{64}$ Nitekim kodein, afyon ile haşhaş kozasında bulunmaktadır. Tıpta kullanılmakta olan kodein, morfinin kimyasal süreçlerden geçirilmesi sonucu elde edilmekte ve azaltılmış morfin olarak bilinmektedir. ${ }^{65}$

XIX. Yüzyılın ikinci yarısında afyonun kimyasal özelliklerinden hareketle elde edilen uyuşturucu maddelerin en önemlilerinden birisi de eroindir. Dr. Felix Hoffman, 1897'de afyon ve morfin üzerinde yaptığı araştırmalar sonrasında, morfini sentezleyerek, eroini üretmiş, bir yıl sonra da Almanya'da seri üretime geçilmişti. ${ }^{66}$ Illaç firmalarına ait laboratuarlarda geliştirilen eroin, ilaç piyasasında önemli bir pazar elde etmeye başlamış ve kısa süre içerisinde dünya genelinde önemli bir pazar payı elde etmişti. Ancak eroinin çeşitli faydalarına rağmen insan sağlığı üzerinde özellikle bağımlılık yapıcı özellikleri, dünyayı etkilediği gibi Osmanlı toplum sağlığını da beraberinde etkilemiştir. ${ }^{67}$ Böylece afyon ve türevlerinin denetimsiz ve plansız kullanımı da ülkeler arasında savaşlara ve çatışmalara neden olabilecek problemleri de beraberinde getirmiştir. Nihayetinde bağımlılık yapıcı özellikleri nedeniyle afyondan uyuşturucu elde edilmesinin sıkı kontrollere tabi tutulması, XX. yüzyılın başlarından itibaren genel kabul görmüştür. ${ }^{68}$

Osmanlı toplumunda uyuşturucu imalinde başvurulan bitkilerden bir diğeri de kenevirdir. Kenevir bitkisi sadece Osmanlılarda değil, daha önceki birçok medeniyette de hastalık ve rahatsızlıklarda ağrı kesici işlevi görmüştür. ${ }^{69}$ Tarihsel süreçte kenevir bitkisini önemli kılan faktörlerin başında kenevirden üretilen esrar gelmektedir. Farklı kullanım alanlarıyla öne çıkan esrar, kenevir bitkisinin kahverengi-yeşil çiçeklerinin karışımından, tohumları ile sapları ve yapraklarından oluşmakta, uyuşturucu bileşenini bünyesinde barındırmaktadır. ${ }^{70}$ THC denilen bileşen, hekim kontrolünde kullanılırsa tedavide etkili bir madde işlevi görmekte, buna karş1 fazla kullanılırsa sersemlik yapmakta ve sinir hücrelerini tahrip etmektedir. Nitekim Ortaçağ

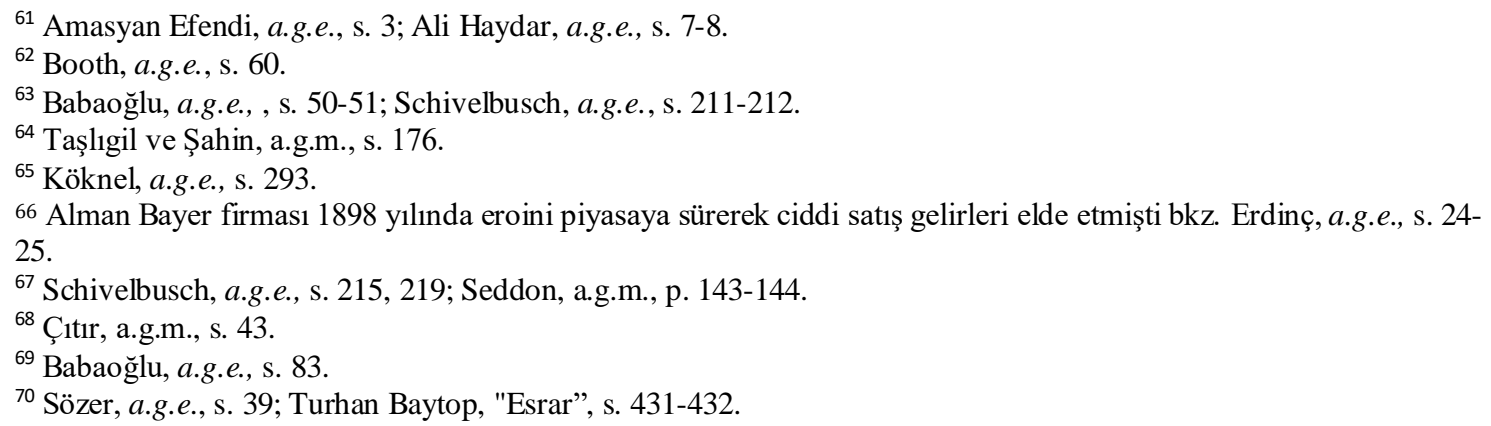


İslam hekimliğinde "haşiş" de denilen esrar, uyku verici ve anestetik gayelerle üretilerek öncelikli olarak esrara cerrahi anestezide müracaat edilmişti. ${ }^{71}$

Osmanlılarda "beng" adıyla zikredilen kenevirden elde edilen esrar, cerrahi işlemler için imal edilmiş olsa da Osmanlı Klasik Dönemi’nden itibaren tıbbî amaçlar dışında keyif amacına yönelik olarak da esrar imali söz konusudur. Bilhassa Süleymaniye semtindeki Tiryakiler Çarşısı'nda yer alan esnaflar, dükkânlarında şurup, macun, plaka gibi esrar ihtiva eden müstahzarlar hazırlardı. ${ }^{72}$ Bunlar içerisinde özellikle şurup (şerbetlere konmak için) ve plaka (tütün ile içmek için) halinde üretilenler daha fazla rağbet görürdü. Şuruplara, esrarın kokusunu gizlemek amacıyla değişik baharat da ilâve edilirdi. Esrar plakası hazırlamak için esrar tozu koyu kahve ile pişirilir ve elde edilen hamur mermer levhalar üzerinde plaka haline getirilirdi. ${ }^{73}$ Esnaflar tarafından hazırlanan bu ürünler, kullanıcılar tarafından talep görmüş ve bu işi yapan esnaf zümresi de tedavi amacı dışında üretilen bu ürünlerden gelir elde etmişti.

\subsection{Haşhaş ve Kenevir Bitkisinden İmal Edilen Afyon ve Esrarın Pazarlama-Satış Süreci}

Osmanlı ticaret sistemi, bütün sektörlerde ve işkollarında esnaf birliği sistemine dayanıyordu. Bu sisteme göre bir malı üretme, satın alma ve satma hakkını elinde bulunduran birlikler dışında kimsenin piyasada alış ve satış yapmasına müsaade edilmiyordu. Osmanlı Devleti'nde uyuşturucu özelliği taşıyan maddelerin pazarlama ve satış süreci de esnaflık sistemine göre şekillenmişti. $^{74}$

Osmanlı esnaflık sisteminin gereği, afyon ve kenevir gibi katma değerli ürünlerin üretim bölgelerinden alınması, belli yerlerde muhafaza edilmesi ve büyük şehirlerin merkezlerinde kurulan çarşılardaki esnafa ulaştırılması, oradan da yetkili çarşı esnafi tarafından satılması, düzenli işleyen bir sistem sayesinde gerçekleşiyordu. ${ }^{75} \mathrm{Bu}$ doğrultuda uyuşturucu özelliği taşıyan malların ticareti, daha önceden belirlenmiş bir prosedüre tabiydi. Bunlar içerisinde talep artı̧̧ları gösteren bir ürün olarak dikkati çeken afyonun üretim mahallinden alınarak tüketiciye ulaştırılmasına kadarki süreç, merkezi idarenin çizmiş olduğu kurallar ve sınırlar çerçevesinde ilerliyordu. ${ }^{76}$

Osmanlı Döneminde afyonun çiftçiden alınıp yurt içi ve yurt dışına satılması, genel olarak toptan veya perakende satış şeklinde gerçekleşmekte ve bu da üç yolla yapılmaktaydı. Bunlar köy satışı, mizan satışı ve toptan satış şeklindeydi. Köy satışı, üreticilerin ihtiyaçları karşılığında aldıkları mal ile afyonun mübadele edilmesiyle yapılmaktaydı. Mizan satışı, çiftçilerin üretmiş oldukları afyonları üretim bölgelerinde mizan denilen müzayede ve tartı yerine getirerek açık arttırma yöntemi ile esnafa satmalarıydı. Toptan satış ise afyon tacirlerinin, köylerden mizan yolu

\footnotetext{
${ }^{71}$ Demirhan, Geçmişte ve Günümüzde Esrar, s. 37.

${ }^{72}$ Evliyâ Çelebi Seyahatnâmesi (I. Kitap), haz. Orhan Şaik Gökyay, Yapı Kredi Yayınları, İstanbul 1999, s. 288; Turhan Baytop, "Esrar", s. 431-432.

73 Turhan Baytop, "Esrar", s. 432.

${ }^{74}$ Ahmet Kala, "Esnaf", DİA, C. 11, TDV Yay., İstanbul 1995, s. 425; Osmanlı esnaflık sisteminde piyasaya mal ile hizmet sunan esnaf grupları arasında XVI. yüzyıl kayıtlarına göre afyoncu esnafı da yer alıyordu. BOA, Topkapı Sarayı Müze Arşivi Defterleri (T.S.MA.d), nr. 1730, 29/12/1576 (08/L/984); BOA, T.S.MA.d, nr. 1796, 29/12/1582 (03/Z/990). 75 “Anadolu'da hâsıl olan bütün afyonların İzir İhtisab Nazırının tezkiresine hâmil kimseler satın alıp, tezkiresiz kimselerin almasına müsaade olunmaması hakkında İzmir İhtisap Nazırı ile Anadolu sancaklarına gönderilen hükmün icrası" BOA, Cevdet Maliye (C.ML), nr. 98/4360, 29/12/1829 (03/B/1245).

${ }^{76}$ BOA, Dahiliye Nezareti Mektubî Kalemi (DH.MKT), nr. 543/60, 11/04/1902 (02/M/1320).
} 
ile satın aldıkları afyonu şehirde tekrar fiyatlandırıp toptan satmaları ile yapılan satış yöntemiydi. ${ }^{77}$

Osmanlı esnaflık teşkilatına göre kendi içinde tutarlılığı olan bu sistemde herhangi bir aksaklık yaşanmaması için devletin ve esnaf teşkilatının ilgili birimleri tarafından azami gayret gösteriliyordu. Özellikle afyon ve esrar gibi ürünlerin başkentte ticaretini tekeli altında bulunduran afyoncu ve benglikçi (esrarcı) esnafına üretim bölgelerinden yükte hafif pahada ağır olan bu malların yolda zayi olmaması için muhafazalı şekilde ulaştırılmasına dikkat ediliyordu. Örneğin bunlar içerisinde yer alan esrar, dıșında k1l ve içinde deri olmak üzere iki torbaya konularak sevk edilir, oradan da piyasaya arz edilmek üzere İstanbul'da yetkilendirilmiş esnaflara teslim edilirdi. ${ }^{78}$ İstanbul'da aktarlar esnafina bağl faaliyetlerini sürdüren afyoncu ve benglikçi (esrarcı) esnafları da elde ettikleri bu ürünleri Osmanlı esnaflık nizamı gereği belirlenen bir fiyat üzerinden piyasaya arz ederlerdi. ${ }^{79}$

Osmanlı ticaret sistemi doğrultusunda esnaflar, faaliyet gösterdikleri işkolları nazara alınarak kendi içinde ayrı birlikler halinde teşkilatlanmıştı. Hatta işin niteliğine göre bazı mal ve hizmet grupları daha alt birimlere bölünerek örgütlenmişti. ${ }^{80} \mathrm{Bu}$ çerçevede diğer mal ve hizmet gruplarında olduğu gibi uyuşturucu maddelerle ilgili de esnaf zümreleri yer almış ve aktarlar esnafı bünyesinde bu esnaflar da İstanbul Süleymaniye'deki "Tiryakiler Çarşısı'nda" afyoncular ve esrarcılar şeklinde kendi içinde ayrılmışlardı. Nitekim Evliya Çelebi buradaki afyoncu esnafa "esnâf-1 ehl-i keyf, afyoncuyân, esnâf-1 ehl-i şevk" adı verildiğini ve çarşıda 104 kişinin bu işten geçimini sağladığından bahsetmektedir. Ayrıca Evliya Çelebi, esrar satışı yapan ve "benglikciyân" adı verilen esnaf zümresinin de 16 dükkândan oluştuğunu ve bu dükkânlarda çalışan sayısının ise 60 kişi olduğunu belirtmektedir. ${ }^{81}$

Volume 12

İstanbul'da afyoncu ve benglikçi (esrarcı) esnafi dışında macuncular esnafi tarafından imal edilen ve içeriğinde bulunan afyondan dolayı uyuşturucu özelliği taşıyan macunlar da belli bir pazara sahipti. ${ }^{82}$ Özellikle bunlar içerisinde yer alan ve diğer pek çok macun türü gibi şifa ve ilaç maksadıyla üretilen Rahîkî macunu XVI. yüzyıldan itibaren büyük bir üne kavuşarak İstanbul dışına da satışı yapılan bir ürün haline gelmişti. ${ }^{83}$ Bu macun türünün uzunca süre varlığını devam ettirmesinde devletin yetki vermiş olduğu esnafı koruyucu ve destekleyici tavrı önemliydi. Çünkü devlet, macunda kalitenin bozulmaması, kontrolsüz şekilde yetkisiz kişilerce üretim ve satış yapılmasını engellemek ve amacı dışında keyif verici olarak kullanılmasını önlemek için üretme ve satma yetkisini Mahmutpaşa'da sadece iki dükkâna vermiş, bu dükkânların fiyatlarını da denetim altında tutmaya gayret etmişti. ${ }^{84}$ Kaynağını Osmanlı esnaflık sisteminde alan ve

\footnotetext{
${ }^{77}$ Çıtır, a.g.m., s. 26; Mizan kelime olarak tartı aleti, tartmada kullanılan ağırlık ve adalet anlamlarına gelmektedir. Bu kavram iktisadî anlamlarının yanı sıra ağırlıklı olarak dinî bir kavram olarak da dikkati çekmektedir. Süleyman Toprak, “Mizan”, DIA, C. 30, TDV Yay., İstanbul 2005, s. 211 (211-212).

${ }^{78}$ Baytop, "Esrar", s. 432;

${ }^{79}$ BOA, C.ML., nr. 450/18215, 29/04/1784 (08/C/1198).

${ }^{80}$ Kala, a.g.m, s. 425-426.

${ }^{81}$ Evliyâ Çelebi Seyahatnâmesi (I. Kitap), haz. Robert Dankoff, Yücel Dağlı ve Seyit Ali Kahraman, Yapı Kredi Yayınlar1, İstanbul 2006, s. 327; Evliyâ Çelebi Seyahatnâmesi (II. Kitap), s. 607-608.

${ }^{82}$ Afyondan elde edilen macunlar sadece İstanbul'da değil, Afyonkarahisar gibi afyon üretimi yapılan kentlerde de bir gelir kaynağıydı bkz. Suraiya Faroqhi, Osmanlı Kültürü ve Gündelik Yaşam (Ortaçağdan Yirminci Yüzylla), Tarih Vakfi Yurt Yayınları, İstanbul 2005, s. 237-238.

${ }^{83}$ Uluskan, a.g.m., s. 82.

84 "İstanbul'da vâki' Mahmud Paşa sûkunda berș tabh ve bey" eden rahîkīnin iki bâb dükkânlarından mâ'adâ mahmiye-i mezbûrede berş tabh ve bey' eden muhdes dükkânlar ta 'tîl ve tabhdan men 'olunmaları bâbinda bundan akdem tuğrâ-yı garrâ ile mu'anven sâdır olan fermân-ı âlîşân mûcebince zikr olunan iki bâb rahîkī dükkânlarından mâ 'adâ muhdes olan dükkânlarmen 've ta 'tîl olunmak takrîbiyle Memâlik-i Mahrûse'de bey' ü şirâ olunan berş ancak
} 
uyuşturucu madde özelliği taşıyan ürünlerin üretim, satış ve dağıtımında bir nizamı öngören bu mekanizma, XVIII. yüzyıl sonlarına kadar önemli bir değişikliğe uğramadan varlığını sürdürmüştü. ${ }^{85}$

Osmanlı coğrafyasında ekimi yapılan haşhaş ve kenevir bitkisinin pazarlama ve satış sürecinde değişimin gerçekleştiği asıl dönem, XIX. yüzyılın başlarıdır. Özellikle bu yüzyılın başında Avrupa da afyon ve kenevire bağlı yeni ilaçlar ve ağrı kesiciler imal edilmesi, haşhaş ve kenevir bitkisine dış talebin ortaya çıkmasına neden olmuştur. Bunlar içerisinde bilhassa afyonunun sentezlenmesi suretiyle morfinin keşfedilmesi ve diğer ülkelere ait afyon çeşitlerinin \% 8-10 oranında morfine sahip olmalarına karşılık özellikle İzmir bölgesi Osmanlı afyonlarının \%12-14 oranında morfin ihtiva etmesi, Avrupa ilaç sanayiinin Osmanlı ürünlerine ilgi göstermesine neden olmuştu. ${ }^{86}$ XIX. Yüzyılın ilk yarısında ağırlıklı olarak dış talebe bağlı gelişen süreç ise Batı Anadolu'da üretimin artmasına ve bunun sonucu olarak da dişarı ile daha rahat temas kurabilen İzmir limanının diğer birçok üründe olduğu gibi uyuşturucu içeriğine sahip maddelerin pazarlama ve satış sürecinde belirleyici bir rol edinmesine yol açmıştır. Nitekim bu dönemde İzmir İhtisab Nâzırı, afyon ve esrar gibi ürünlerin üretim ve satışının koordinasyonu ile denetiminde devlet adına tek yetkili konumuna gelmişti. ${ }^{87}$ Bunda şüphesiz bir iktisat politikası olarak "yed-i vâhit" sistemine geçilmesinin payı da bulunmaktayd $1 .{ }^{88}$

Dış ticareti kontrol altında tutmayı amaçlayan bu sistem; önce palamut, mazı, kök boya, incir, zeytinyağı, ipek gibi hammaddelere daha sonra ise afyona uygulandı ve bu sistemin en uzun sürdügü, kendisini en somut şekilde gösterdiği alanların başında afyon yer ald $1 .{ }^{89}$ Bu uygulamaya göre tezkereli tüccarlar üreticilerden devletçe belirlenen fiyattan satın aldıkları afyonu, İzmir'de bütün ek vergilerini ödedikten sonra kendi mutedil kârlarını da ekleyerek İhtisab Nâzırına satacak; tezkereli tüccarların dışında ise yalnız üreticiler ürününü getirip satabilecek, tezkereli tüccar da İzmir'den başka yere götürüp sattığı takdirde tezkeresi elinden alınarak bu ticaretten menedilecekti. ${ }^{90}$ Yed-i Vâhid uygulamasına afyonu Osmanlı'dan ithal eden devletler şiddetle karşı çıkarken; hazine, yed-i vâhid uygulamasından kazançlı çıkıyordu. ${ }^{91}$ Aşağıdaki tablo bu durumu açık bir şekilde göstermektedir.

zikr olunan iki bâb dükkânlara maksûr olmağın...." İstanbul Kadı Sicilleri, İstanbul Mahkemesi 24 Numaralı Sicil, Belge nr. 20b-2, Cilt 21, s. 131. 04/07/1726 (04/ZA/1138).

${ }^{85}$ BOA, Cevdet Maliye (C.ML), nr. 665/27219, 29/03/1783 (24/RA/1197); BOA, C.ML, nr. 540/22213, 29/04/1793 (18/N/1207).

${ }^{86}$ Osmanlı coğrafyasında İzmir, İstanbul, Mısır olmak üzere başlıca üç nevi afyon vardır. İzmir afyonu saf ve morfin oranı yüksek olduğundan makbuldür ve \%12-14 kadar morfin havidir. Bunu sirasıly İstanbul ve Misır afyonu izlemektedir. Asuman Baytop, Türkiye'de Botanik Tarihi Araştırmaları, Tübitak Yayınları, Ankara 2004, s. 297; Çıtır, a.g.m., s. 25-26; Burak Çıtır, Osmanlı'dan Cumhuriyet'e Türkiye'de Afyon Ziraati ve Ticareti (1900-1939), (Yayınlanmamış Yüksek Lisans Tezi, Sakarya Üniversitesi Sosyal Bilimler Enstitüsü), Sakarya 2015, s. 34.

${ }^{87}$ BOA, Cevdet Maliye (C.ML), nr. 98/4360, 29/12/1829 (03/B/1245); BOA, Hatt-ı Hümâyun (HAT), nr. 659/32171, 29/12/1831 (24/B/1247).

${ }^{88}$ Yed-i vâhid sistemi, bazı malların üreticilerden satın alınıp büyük mübadele merkezlerine taşınması ve orada ekseri olarak ihraç edilmek üzere yabancı tüccara, bazı durumlarda perakende satıcılarına toptan satılmasının devlet kontrolü ve sermayesiyle örgütlenmesi şeklinde 1826-1838 yıllarında Osmanlı Devleti'nde uygulanan bir ticaret tekeli rejimiydi. Ayrıntılı bilgi için bkz. Mehmet Genç, "Yed-i Vâhid", DİA, C. 43, TDV Yay., İstanbul 2013, s. 378.

89 Mübahat Kütükoğlu, Osmanl-IIngiliz İktisadi Münasebetleri I (1580-1938), Ankara 1974, s. 65.

${ }^{90}$ Genç, a.g.m., s. 382.

${ }^{91}$ Yed-i vâhid uygulamasında iç ticarette üreticilere ödenen fiyatların nispeten düşük düzeyde tutulduğu yine afyon örneğinde görülmektedir. Tablo 2'de 1 çeki afyon için üreticilere yed-i vâhidin başladığı 1830 yılında ödenen 45 kuruş, 1835 'te sadece \%20 artışla 54 kuruşa çıkarılmıştır; aynı yıllarda İstanbul'da enflasyon oranı \%60'a yaklaştı̆̆ına göre yapılan zammın üreticiye fazla bir katkısının olmadığı, buna mukabil bu dönemde afyon ihracatında aradaki fark ın hazineye gelir olarak kaydedildiği anlaşılmaktadır. Ayrıntılı bilgi için bkz. Genç, a.g.m., s. 382 
Kaya Göktepe

Tablo: 21000 Çeki (800 kg.) Afyon İçin İngiltere’nin Ödediği Fiyat (Sterlin)

\begin{tabular}{|l|l|}
\hline Yillar & Fiyat (£) \\
\hline 1831 & 1092 \\
\hline 1832 & 1363 \\
\hline 1833 & 1422 \\
\hline 1835 & 980 \\
\hline 1843 & 700 \\
\hline 1846 & 630 \\
\hline
\end{tabular}

Kaynak: Mehmet Genç, “Yed-i Vâhid”, DİA, C. 43, İstanbul 2013, s. 382.

Tablo 2 incelendiğinde sistemin etkin şekilde uygulandığı özellikle 1831-1833 arasında afyon ihraç fiyatlarında yüksek oranda bir artış kaydedildiği anlaşılmaktadır. Diğer taraftan "yed-i vâhid" uygulamasının sona erdiği tarihten itibaren ise afyon ihraç fiyatlarının belirgin biçimde düşme eğilimine girdiği görülmektedir. Bu fiyat düşüşünün İngiltere başta olmak üzere diğer Avrupa ülkelerinin arzu ettiği bir durum olduğu anlaş1lmaktadır. Şüphesiz, Avrupa ülkeleri lehine bir durumun yaşanmasında o dönem için önemli bir iktisat politikası değişikliğine sebebiyet veren faktörlerin başında Osmanlı ile İngiltere arasında imzalanan ticaret antlaşması gelmektedir.

Osmanlı Devleti ile İngiltere arasında imzalanan 1838 tarihli Baltalimanı Ticaret Antlaşması, Osmanlı Devleti'nin uluslararası ticaretinde köklü değişikliklere yol açmıştır. Antlaşmayla birlikte Osmanlı topraklarında öteden beri uygulanan ihraç yasakları tamamen kaldırılıyor, yabancı tüccar her istediği malı satın alma imkânını kazanıyordu..$^{92}$ Böylece Osmanlı Devleti'nde yüzyıllardır ekonomide değişmez prensipler yavaş yavaş değişmeye başlamış, yabancı ülkelerin Osmanlı tarım ürünlerine ilgisi daha da artmıştı.93 Bu kapsamda artık ihracat üzerindeki kısıtlamalar da zamanla kalkmaya başlayınca dünya ölçüsünde şekillenen uluslararası işbölümünün gereği olarak Osmanlı topraklarında ziraî ürünlere yönelen dış talep, Osmanlı tarımının performansında ve yapısında da değişimlere neden olmuştu. Bu değişimlerden en fazla etkilenen ve dişarıda en fazla talep gören tarımsal ürünlerden birisi de haşhaştan elde edilen afyondu.94

XIX. yüzyılın ikinci yarısından itibaren yabancıların ticaret yapmaları üzerinde kısıtlamalar kalkmaya başlayınca, Osmanlı afyonu birçok ülke piyasasına ihraç edilmeye başlamıştı. Bunların başında İngiltere geliyordu. ${ }^{95} \mathrm{Bu}$ ülkeyi Almanya, ABD, Fransa, Hollanda, Avusturya-

\footnotetext{
92 Mübahat Kütükoğlu , "Baltalimanı Muahedesi”, DİA, TDV Yay., C. 5, İstanbul 1992, s. 39; Baltalimanı Ticaret Antlaşması ve maddeleri hakkında ayrıntılı bilgi için bkz. Kütükoğlu, a.g.e., s. 65; Mübahat Kütükoğlu, OsmanlIngiliz İktisadi Münasebetleri II (1938-1850), Ankara 1976.

93 Mehmet Genç, Osmanlı İmparatorluğunda Devlet ve Ekonomi, Ötüken Yayınları, İstanbul 2005, s. 93.

94 Tevfik Güran, 19. Yüzyıl Osmanlı Tarımı, Eren Yayınları, İstanbul 1998, s. 58.

95 1827-1900 yılları arasında İngiltere'nin afyon ithal ettiği ülkeler sıralamasında Osmanlı Devleti XIX. yüzyılda sürekli olarak birinci sırada yer almıştı. Bu kapsamda 1827-1900 arasında İngiltere'nin toplam afyon ithalatı içerisinde Osmanlı afyonunun ağırlı̆̆ birkaç yıl istisna tutulursa \%65-\%99 arasında değişmekteydi. Ayrıntılı bilgi için bkz. Virginia Berridge, Opium And The People (Opiate Use and Drug Control Policy in Nineteenth and Early Twentieth Century England), London 1999, p. 292-293; Booth, a.g.e., s. 45; 1860-1862 yıllarından itibaren 1910-1912 y1llar1 arasına kadar Osmanlı'dan İngiltere'ye yapılan toplam ihracata bakıldığında ise Osmanlı toplam ihracatı içerisinde afyonun payı genel olarak \%5 dolaylarındadır. Diğer taraftan bu dönemde dünya sahnesine yeni çımaya başlayan ABD'ye yapılan ihracatın 1880-1882 yılları arasında yaklaşık \%23'ünü afyon oluşturuyor, ancak ilerleyen y1llarda
} 
Macaristan, İtalya, Romanya, Japonya, Yunanistan, Mısır, Rusya, Belçika, Lehistan, İsveç ve Danimarka gibi ülkeler takip ediyordu. ${ }^{96}$

Avrupa'da sağlık sektöründe aranan bir ürün olarak dikkati çeken afyon, XIX. yüzyılın ikinci yarısından itibaren en fazla ihraç edilen tarım ürünleri arasına girmeyi başarmıştı. Örneğin 1897 yılına gelindiğinde Osmanlı tarım ürünleri ihraçları arasında üzüm, incir, zeytinyağından sonra dördüncü sırada 62 milyon kuruşluk değeriyle afyon yer alıyordu. Diğer taraftan toplam mal ve ürün ihracatında ise afyon, altıncı sırada kendine yer buluyordu. ${ }^{97} \mathrm{Bu}$ doğrultuda XIX. yüzyılda yurt içi talebin yanı sıra ağırlıklı olarak yurt dışında ciddi alıcı bulan Anadolu afyonu, 1888 yılı öncesinde toplam Anadolu ihracatının \%12 kadarını oluşturuyordu. Ancak bu tarihten sonra otuz yıllık süre zarfinda oran yaklaşık olarak \%5'e kadar düşmüştü. ${ }^{98}$ Aşağıdaki şekil buna benzer biçimde Osmanlı Devleti'nin genel durumunu ortaya koymaktadır.

Grafik: 2 Osmanlı Devleti'nin Toplam İhracatı İçerisinde Afyon İhracatının Yıllara Göre Yüzdelik Değişimi (1878-1913)

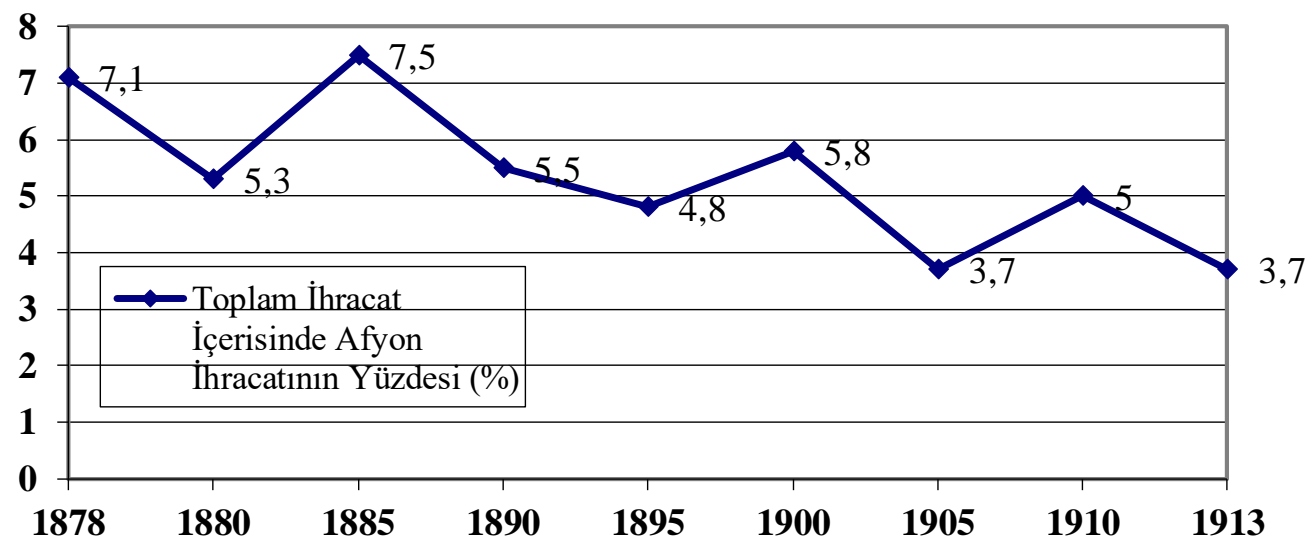

Kaynak: Pamuk, a.g.e., s. 37-42; Celal Aybar, Osmanlı Imparatorluğu'nun Ticaret Muvazenesi 1878 1913, Ankara 1939, s. 55-64.

1875 ve sonrasındaki süreçte Osmanlı afyon üretim durumunu gösteren Tablo 1, Grafik 1 ve Grafik 2 birlikte değerlendirildiğinde, 1885 yılına kadar bazı yıllar istisnai olarak toplam ihracat içerisinde afyon ihracatında düşüş yaşanmış olsa da genel olarak toplam ihracat içerisinde afyonun \%7 civarındaki payını koruduğu görülmektedir. Ancak bu dönemden sonra bilhassa 1890 sonrasındaki sürece bakıldığında uygulanan teşvik politikalarının da etkisiyle afyon üretim miktarında gözle görülür bir artış kaydedilmesine rağmen afyonun toplam ihracat içerisindeki payının düşüş eğilimi gösterdiği dikkati çekmektedir. Bunda diğer ürün ve malların ihracatta payının artması, uluslararası konjonktürde bağımlılık yapıcı etkisi nedeniyle afyon üzerinde

afyonun oranı, 1900-1902 arasında \%9'lara, 1910-1912 yılları arasında da \%7,5 seviyelerine düşüyordu. İstatistiklerin ayrıntılı dökümü için bkz. Pamuk, a.g.e., s. 62-64.

${ }^{96}$ Çolak, a.g.m., s. 522.

97 Donald Quataert, "The Ages Of Reforms 1812-1914”, An Economic and Social History of the Ottoman Empire 1300-1914, Ed. Halil İnalc1k ve Donald Quataert, Cambridge Univ. Press, 1996, s. 833.

${ }^{98}$ Quataert, a.g.e., s. 244-246. 
uluslararası arenadaki kısıtlayıcı politikalar ile afyon ihracat birim fiyatlarında kısmi düşme eğiliminin etkisinin bulunduğu anlaşılmaktadır.

Afyon satış fiyatındaki dalgalanmaları göstermesi açısından XIX. Yüzyılın son çeyreğinden itibaren (1878-1913) afyon ihracat satış fiyat ortalamalarına bakıldığında, bu durum rahatlıkla görülebilmektedir. Nitekim 1878 yılında 1 kilo afyonun ihracat satış fiyatı 1,72 lira iken, 1880 yılında, 1,74 lira, 1885 yılında 1,61 lira, 1890 yilında 1,64 lira, 1895 yılında 1,70 lira, 1900 yılında 1,61 lira, 1905 yılında 1,67 lira, üretim miktarının arttığ 1910 yılında 1,80 lira ve 1913 yılında da 1,16 liraya kadar düşmüştü. ${ }^{99}$

Bütün bu gelişmelerin yanı sıra dünyada özellikle XX. yüzyılın başında Amerika ve Avrupa'da keyif verici madde kullanım oranının artmasından dolayı ABD öncülüğünde afyon ve alkaloitlerine karşı uluslararası müdahaleler gündeme gelmiştir. Bu amaç doğrultusunda 1909 tarihli Şangay ve devamında Konferansı ve 1911, 1913 tarihinde de Lahey'de konferanslar düzenlenerek afyon ve türevi ürünlerin kısıtlanmasına yönelik önlemler ile afyonun ticari durumu kontrol altına alınmaya çalışılmıştır. ${ }^{100}$ Uluslararası arenada yaşanan afyonla ilgi bu tür gelişmelerin ise afyon ihracatçısı bir ülke olarak Osmanlı Devleti'nin afyon ihracat miktarlarında ve fiyatlarında düşüşe etki ettiği anlaşılmaktadır. Ayrıca ülkenin içine girmiş olduğu savaş koşullarının da yine bu süreçte afyonu olumsuz etkilediği görülmektedir.

Osmanlı Döneminde afyon kadar uluslararası ticarete konu olmasa da özellikle yurt içi piyasada ticarete konu olan uyuşturucu maddelerin hammadde kaynaklarından birisini de kenevirden elde edilen esrar oluşturuyordu. Döneme ait kayıtlarda "beng" adıyla zikredilen esrar ve bu işi yapan esnafa da "benglikçi esnafi" adı verilen bir esnaf zümresi bulunuyordu ve Osmanlı esnaf teşkilatı nizamı, bu esnaf zümresi için de geçerliydi. Bu minvalde aktarlar esnaf grubuna bağlı olarak faaliyetlerini yürüten benglikçi esnafinın aktarlar içerisinde yer alması, esrarın sağlık alanının bir ürünü olduğuna delâlet etmektedir. Ancak esrar her ne kadar sağlık alanında ağrı giderici ve tedavi edici bir ürün olarak bilinse de bağımlılık yapabilme özelliği taşımaktaydı. Özellikle arşiv kayıtlarında benglikçi esnafının bunu imal ederek tiryakilere sattığına yönelik çeşitli şikâyetler de bulunuyordu. Bu şikâyetler üzerine devlet yönetimi hem kenevir ekimini hem de esrar imalatı ve satışını denetim altına almaya gayret ediyordu. Çünkü uyuşturucu özelliği taşıyan maddelerin denetimsiz şekilde satılması toplum sağlığını olumsuz etkileme riski taşıdığından devlete önemli roller düşüyordu. ${ }^{101}$

Osmanlı Devleti'nde esrar ve diğer uyuşturucu içerikli ürünler, sağlık amacıyla piyasaya arz edilse de keyif amacıyla da kullanıma sahip olduğu için Klasik Dönem ve devamında devlet tarafından arzdan başlamak üzere talebi engellemeye varıncaya kadar mücadele çalışmaları sürdürülmüştü. $\mathrm{Bu}$ doğrultuda benglikçi ve macuncular adındaki belli esnaf zümrelerinin uhdesine verilen ürünlerin gayri resmî kullanımını önlemeye yönelik ekonomik yaptırımlara başvurulmuştu. Özellikle "Tiryakiler Çarşısı" ve burada yer alan dükkânlar ile Mahmutpaşa civarındaki macuncular esnafi dükkânları, Osmanlı Devleti'nin esnaf nizamı çerçevesinde sık sık denetlediği yerler olarak ön plana çıkmıştı. ${ }^{102}$

\footnotetext{
${ }^{99}$ Pamuk, a.g.e., s. 42.

${ }^{100}$ Suna Altan, "Cenevre Afyon Konferansları ve Türkiye'nin Tutumu", Çanakkale Araştırmaları Türk Yıllı̆̆g, Bahar 2019, S. 26, s. 49-51.

${ }^{101}$ BOA, Şûrây-ı Devlet (Ş.D), nr. 290/44, 21/01/1882 (01/RA/1299); BOA, Zabtiye Nezareti (Z.B), nr. 601/130, 02/12/1906 (15/L/1324).

${ }^{102}$ BOA, Cevdet Maliye (C.ML), nr. 665/27219, 29/03/1783 (24/RA/1197); BOA, C.ML, nr. 540/22213, 29/04/1793 (18/N/1207).
} 
Esrar maddesinin alış ve satış hakkını benglikçi esnafına veren ve onların satışlarını denetleyen devlet yönetimi, daha önceki yüzyıllarda olduğu gibi XIX. yüzyılda da bu malın yetkisiz kişilerin eline geçmesini ve oradan da kayıt dışı olarak piyasaya arz edilerek maddenin keyif amacıyla kullanılmasını önlemeye çalışmaktaydı. Ancak bu maddenin ticaretini sadece bir esnaf grubuna vermekle ve onların satışlarını denetlemekle bu politikanın tam anlamıyla başarıya ulaştı̆̆ını söylemek güçtür. Çeşitli arşiv kayıtlarında da esrar (beng) ticaretinin yetkisiz kişilerin veya kaçakçıların eline geçtiği de anlaşılmaktadır. Devlet bu fiili durumun önüne geçebilmek için XIX. yüzyılın ortasında esrar ekimi ile kullanımını yasak kapsamına almaya çalışmıs ve yasağı bir müddet katı bir şekilde uygulamıştı. ${ }^{103}$

Osmanlı Devleti tarafından keyif verici maddelerin arzını önlemeye yönelik çalışmalar XIX. yüzyılın ikinci yarısında kararlılıkla devam etmiş, özellikle izinsiz satış yapanlara yönelik ağır sayılabilecek cezalar dikkati çekmişti. Bu cezaların başında ise hapis, sürgün ve zorunlu olarak kamu yararına çalışma cezaları geliyordu. ${ }^{104}$ Buna karşılık dünyada bu dönemde özellikle İngiltere ve Amerika gibi uluslararası topluma yön veren ülkelerin yanı sıra Orta Doğu'da afyon ve esrar gibi maddelere yasaklama ve cezalandırma yoluna gidilmeyerek maddelerin keyif verici olarak kullanılmasına hoşgörü ile yaklaşıldığı bilinmekteydi. ${ }^{105}$ Nihayetinde XIX. yüzyılın sonu ve XX. Yüzyılın başından Cumhuriyet'e devam eden süreçte, uyuşturucu maddelerin yurtiçinde arzını önleme çabaları kapsamında devletin iktisadî, hukukî ve idarî alandaki mücadele çalışmaları aynı şekilde sürdürülmüştü. ${ }^{106}$

\section{Sonuç}

Uyuşturucu maddeler, tarihsel süreç içerisinde tıbbî sahada ağrı giderici ve tedavi edici özellikleri nedeniyle köklü bir geçmişe sahip olmuş ve uyuşturucu maddeye kaynaklık eden bitkilerden haşhaş ve kenevirden elde edilen afyon ve esrar, doğal uyuşturucu grubu içerisinde hekimlerin sıklıkla müracaat ettiği ürünler arasında yer almıştır. Afyon ve esrarın tıbbî gerekçeler dışında ayrıca eski medeniyetlerden itibaren keyif verici ürünler olarak kullanılması, bu maddelerin farklı piyasalarının oluşmasına zemin hazırlamıştır. Dolayısıyla ilk önce sağlık alanında kullanılan bu maddeler, daha sonraları illegal bir şekilde keyif amacıyla tüketilmeye başlamıştır. Afyon ve esrarın farklı amaçlarla kullanılması ise her bir amaca uygun tüketimi besleyecek arz piyasasını da beraberinde şekillendirmiştir.

\footnotetext{
${ }^{103}$ BOA, Irade Dâhiliye (İ.DH), nr. 229/13732, 25/04/1851 (23/C/1267).

${ }^{104}$ Esrar kullanımının yasaklanarak, satanların cezalandırılması hakkında bkz. BOA, Sadaret Nezaret ve Devair Evrakı (MKT.NZD), nr. 77/17, 12/07/1853 (05/L/1269); Kahvesinde esrar içirmiş olan kahvehane sahiplerine hapis cezas1 verilmişti. BOA, $M V L$, nr.179/59, 15/05/1857 (21/N/1273); BOA, MKT.MHM, nr. 489/10, 22/06/1886 (20/N/1303); Farklı bir ceza yöntemi olarak dikkati çeken kamu yararına çalışma cezası kapsamında bazı esrar satıcıları da iplikhaneye zorunlu çalışmaya gönderilmişti. BOA, Meclis-i Vâlâ (MVL), nr.179/53, 18/05/1857 (24/N/1273).

${ }^{105}$ XIX. Yüzyılda dünya politikasında belirleyici konumda bulunan İngiltere'de bile 1868 y1lına kadar uyuşturucu özelliği bulunan maddelerin kullanımına yönelik herhangi bir kısıtlayıcı düzenleme söz konusu değildir. Ayrıntılı bilgi için bkz. Berridge, a.g.e., p. 118-121; Virginia Berridge, "Two Tales of Addiction; Opium and Nicotine", Human Psychopharmacology, Vol. 12, London 1997, p. 45-46; Bayraktar, a.g.m., s. 50.

${ }^{106}$ BOA, Şûray-ı Devlet (Ş.D), nr. 1178/13, 21/07/1885 (08/L/1302); BOA, Meclis-i Vâla (MVL), nr. 180/79, 06/06/1857 (13/L/1273); BOA, Sadaret Mühimme Kalemi Evrakl (A.MKT.MHM), nr, 489/10, 22/06/1886 (20/N/1303), BOA, Dahiliye Nezareti Tesri-i Muamelât ve Islahat Komisyonu (DH.TMIK.M), nr. 168/9, 29/01/1905 (23/ZA/1322); BOA, Dahiliye Nezâreti İdare Evrakı (DH.ID), nr. 87/30, 04/05/1911 (05/CA/1329); BOA, DH.MKT, nr. 946/6, 06/02/1906 (11/Z/1323); Alınan asayiş önlemleri kapsamında özellikle geçmişten beri kullanımının yoğun olduğu İstanbul'da Tahkatale ve Sultanahmet civarındaki kahve ve evlerde belli aralıklarla esrar araması yapılmaktayd1. BOA, ZB, nr. 308/50, 18/05/1905 (13/RA/1323); BOA, Dahiliye Nezareti Mebâni-i Emiriye Hapishaneler Müdüriyeti Müteferrik Evrakl (DH.MB.HPS.M), nr. 46/17, 16/09/1920 (02/M/1339); BOA, DH.MB.HPS, nr. 165/76, 29/09/1919 (04/M/1338).
} 


\begin{abstract}
Afyon ve esrar, Türk-İslâm hekimlerinin tedavide yaygın şekilde kullandığı için ilaç kategorisinde değerlendirilmekle birlikte aynı dönemde aleni olmayan şekilde kullanılan keyif vericiler olarak da dikkati çekmiş ve bu durumun Osmanlı toplumuna da sirayet ettiği görülmüştür. Nitekim Osmanlı coğrafyasında üretilen ve farklı amaçlara hizmet eden afyon ve esrar maddelerinin üretimden başlayarak pazarlama, satış ve tüketime varıncaya kadarki süreçleri içine alan önemli bir iktisadî mekanizmaya sahip olduğu görülmüş olup bu mekanizmanın oluşturulmasında ve varlığını sürdürmesinde ise Osmanlı devlet politikalarının belirleyici bir rolünün olduğu dikkati çekmiştir. Buna göre Osmanlı ekonomisinin temeli olan ziraî ekonomiden başlamak üzere, önce belirlenen yerlerde ürünlerin ekilmesi ve toplanması, akabinde bu ürünlerin mahallinde yetkilendirilmiş esnaflara verilmesi, esnaflar veya görevliler tarafından satın alınan ürünlerin özellikle başkent İstanbul'da Tiryakiler çarşısında belirlenen esnaflara ulaştırması, bir sistem sayesinde mümkün olmuştur. Daha sonra ürünleri satma yetkisi verilen çarşı esnafları tarafından da esnaflık nizamı gereği belli fiyattan ve kaliteden piyasaya arz edilerek tüketicilere ulaştırılması, bu sistemin devletin belirlemiş olduğu sınırlar dâhilinde işlediğini göstermiştir.
\end{abstract}

Osmanlı Klasik Dönemi'nde ekonomik ve sosyal yapının prensipleri doğrultusunda iç talebe hizmet eden bu arz piyasasının XIX. yüzyılın ilk yarısındaki ekonomik ve sosyal değişim sürecine kadar devam ettiği görülmüştür. XIX. yüzyılda Osmanlı iktisadi prensiplerinde yaşanan değişimle birlikte artık uyuşturucu madde kaynaklarının arz-talep piyasasının dış talep eksenine oturduğu dikkati çekmiştir. Bu doğrultuda XIX. yüzyılda ihracat üzerinde gümrük vergilerinin düşürülmesinin de etkisiyle Osmanlı coğrafyasında elde edilen kaliteli afyona Avrupa ilaç sanayiinde ciddi talep oluşmaya başlamıştır. Bilhassa XIX. yüzyılda Avrupa'da afyonun sentezlenmesiyle morfin ve eroin gibi ürünlerin elde edilmesiyle birlikte artık afyon, katma değerli bir sınaî ürün pozisyonuna gelmiş ve kalitesi kanıtlanmış Osmanlı afyonları da Avrupa ülkelerinin en fazla aranan ürünleri arasında yer almıştır. Özellikle1825-1900 yılları arasında İngiltere'nin afyon ithalatının bu dönemde yarıdan fazlasının Osmanlı afyonundan karşılanması, bu durumun en önemli göstergelerindedir.

Uyuşturucu madde kaynağı bitkilerden afyon ve esrar, XIX. yüzyıldan itibaren ciddi talep görse de afyondan elde edilen morfin, kodein ve eroin ile esrarın tıbbî alandaki faydaları yanında keyif amacıyla kullanımdan kaynaklı bir bağımlı kitlesinin oluşması, XIX. yüzyılın sonlarından itibaren afyon ve esrarın uluslararası arenada bağımlılık ekseninde değerlendirilmesine yol açmıştır. Bunun sonucunda uluslararası baskılar neticesinde Osmanlı ürünleri ciddi kısıtlamalara sahne olmuş ve bu da devletin gelir kaybına sebebiyet verdiğinden, dış talep ekseninde gelişen arz piyasası da böylelikle XX. yüzyılın başlarından itibaren kesintiye uğramıştır.

Osmanlı Döneminde uyuşturucu madde kaynaklarından haşhaş ve kenevir bitkisinin arz boyutunu tahlil etmeye çalışan bu araştırmada da görüldüğü gibi Osmanlılarda afyon ve esrar gibi ürünlere öncelikli olarak sağlık sektörü perspektifinden yaklaşıldığı, arz piyasasının da bu sistemi muhafaza etmeye yönelik hizmet ettiği görülmüştür. Buna karşı dinî, sosyal, kültürel, fiziksel, psikolojik vb. açılardan zararlı ve sakıncalı kabul edilen keyif amacıyla kullanıma yönelik bir arz düzenine Avrupa ülkelerinde XIX. yüzyılın sonlarına kadar gösterilen müsamahalı yaklaşımın Osmanlı Devleti tarafından gösterilmediği, bunun yerine devletin ilk dönemlerden itibaren mücadele politikalarını benimsendiği dikkati çekmiştir. 


\section{Kaynakça}

\section{Osmanlı Arşivi Kaynakları}

BOA, Ali Emiri Selim (AE.SSLM.III), nr. 4731.

BOA, Cevdet Evkaf (C.EV), nr. 626/31551.

BOA, Cevdet Maliye (C.ML), nr. 98/4360, 180/7611, 253/10464, 450/18215, 540/22213, $665 / 27219$.

BOA, Dahiliye Nezâreti İdare Evrakı (DH.ID), nr. 87/30.

BOA, Dahiliye Nezareti Mebâni-i Emiriye Hapishaneler Müdüriyeti (DH.MB.HPS), nr.165/76.

BOA, Dahiliye Nezareti Mebâni-i Emiriye Hapishaneler Müdüriyeti Müteferrik Evrak (DH.MB.HPS.M), nr. 46/17.

BOA, Dahiliye Nezareti Mektubî Kalemi (DH.MKT), nr. 543/60, 946/6.

BOA, Dahiliye Nezareti Tesri-i Muamelât ve Islahat Komisyonu (DH.TMIK.M), nr. 168/9.

BOA, Hatt-ı Hümâyun (HAT), nr. 659/32171.

BOA, Irade Dâhiliye (I.DH), nr. 229/13732.

BOA, Irade Rüsumat (I.RSM), nr. 32/36.

BOA, Meclis-i Vâlâ Riyâseti (MVL), nr. 179/53, 179/59, 180/79.

BOA, Sadaret Mühimme Kalemi Evrakı (MKT.MHM), nr. 489/10.

BOA, Sadaret Nezaret ve Devair Evraka (MKT.NZD), nr. 77/17.

BOA, Şûrây-ı Devlet (Ş.D), nr. 290/44, 1178/13.

BOA, Topkapı Sarayı Müze Arşivi Defterleri (T.S.MA.d), nr. 1730, 1796.

BOA, Zabtiye Nezâreti (ZB), nr. 308/50, 601/130.

BOA, Dahili Mektûbat (DH.MKT), nr. 2370/7.

BOA, Hazine-i Hâssa Nezâreti Defterleri (HH.d), nr. 24838.

BOA, Maliyeden Müdevver Defter (MAD.d), nr. 8312, 9674.

BOA, Sadaret Mektubî Kalemi (A.MKT), nr. 28/57.

\section{Basılı Eserler ve Tezler}

ALİ HAYDAR, Haşhaş Ziraatı, Matbaa-1 Osmaniyye, Dersaadet 1330.

AMASYAN EFENDİ, Afyon Tohumu Ziraatı Layihası, La Türki Matbaası, İstanbul 1287.

ATAR, Abdulkadir, Şeyhülislam Fetvaları Işı̆̆ında Osmanlı'da İktisadi Hayat, Albaraka Yay., İstanbul 2020.

AYBAR, Celal, Osmanl İmparatorluğu'nun Ticaret Muvazenesi 1878-1913, Ankara 1939.

BABAOĞLU, Ali Nahit, Uyuşturucu ve Tarihi, Kaynak Yayınları, İstanbul 1997.

BAYTOP, Asuman, Türkiye'de Botanik Tarihi Araştırmaları, Tübitak Yayınları, Ankara 2004.

BERRIDGE, Virginia, Opium And The People (Opiate Use and Drug Control Policy in Nineteenth and Early Twentieth Century England), London 1999. 
BOOTH, Martin, Haşhaştan Eroine Uyuşturucunun 6000 Yıllık Öyküsü, Sabah Kitapları, İstanbul 1996.

BOSTAN, İdris, Osmanlı Bahriye Teşkilâtı: XVII. Yüzyılda Tersâne-i Amire, Türk Tarih Kurumu Yayınları, Ankara 1992.

BULDUK, Üçler, XVI. Asırda Karahisar-ı Sahib Sancă̆ı, (Yayınlanmamış Doktora Tezi, Ankara Üniversitesi Sosyal Bilimler Enstitüsü), Ankara 1993.

ÇITIR, Burak, Osmanlı'dan Cumhuriyet'e Türkiye'de Afyon Ziraati ve Ticareti (1900-1939), (Yayınlanmamış Yüksek Lisans Tezi, Sakarya Üniversitesi Sosyal Bilimler Enstitüsü 2015).

DEMIRBAŞ, Timur, Kriminoloji, 2. Baskı, Seçkin Yayıncılık, Ankara 2005.

DEMIRHAN, Ayşegül, Geçmişte ve Günümüzde Esrar, İstanbul Üniversitesi İstanbul Tıp Fakültesi Yay. 1979.

DEVELIOĞLU, Ferit, Osmanlıca Türkçe Ansiklopedik Lûgat, Aydın Kitabevi, 30. Bask1, Ankara 2013.

DÖNMEZER, Sulhi, Kriminoloji, Beta Yayınevi, 8. Bask1, İstanbul 1994.

EGM. KAÇAKÇILIK VE ORGANIZE SUÇLARLA MÜCADELE DAİRE BAŞKANLIĞI, Kaçakçılık ve Organize Suç Terimleri/Kaçakçılık ve Organize Suçlarla Mücadele Rehberi V. Emniyet Genel Müdürlüğ̈ KOMDB Yayınları, Yayın No: 2002/4, Ankara, 2002.

ERDEMIR, Ayşegül Demirhan, Afyon ve Tıbbi Etik (Ve Diğer Bă̆ımlılık Yapan Maddeler), Bursa 1996.

ERDİNÇ, F. Cengiz, Overdose Türkiye, İletişim Yayınları, İstanbul 2004.

EVLIYÂ ÇELEBİ SEYAHATNÂMESİ (I. Kitap), haz. Orhan Şaik Gökyay, Yapı Kredi Yayınları, İstanbul 1999.

(II. Kitap), haz. Seyit Ali Kahraman ve Yücel Dağl1, Yapı Kredi Yayınları, 5. Bask1, İstanbul 2008.

FAROQHI, Suraiya, Osmanlı Kültürü ve Gündelik Yaşam (Ortaçağdan Yirminci Yüzyıla), Tarih Vakfi Yurt Yayınları, İstanbul 2005.

Osmanlı'da Kentler ve Kentliler, Çev. Neyyir Kalaycıoğlu, Tarih Vakfı Yurt Yayınları, İstanbul 2000.

FOXCROFT, Louise, The Making of Addiction (The 'Use and Abuse' of Opium in NineteenthCentury Britain), Published by Ashgate, England 2007.

GELiBOLULU MUSTAFA ÂLİ, Mevâidü'n-Nefâis Fî Kavâidi'l Mecâlis I (Görgü ve Toplum Kuralları Üzerinde Ziyâfet Sofraları), haz. Orhan Şaik Gökyay, İstanbul 1978.

GENÇ, Mehmet, Osmanlı Imparatorluğunda Devlet ve Ekonomi, Ötüken Yayınları, İstanbul 2005.

GÜNAL, Yılmaz, Uyuşturucu Madde Suçları, Kazancı Yayınları, Ankara 1976.

GÜRAN, Tevfik, 19. Yüzyıl Osmanlı Tarımı, Eren Yayınları, İstanbul 1998.

İSTANBUL KADI SİCILLERİ, İstanbul Mahkemesi 24 Numaralı Sicil, C. 21, Türkiye Diyanet Vakfi İslâm Araştırmaları Merkezi Yayınları. 
KÖKNEL, Özcan, Băğımlılık (Alkol ve Madde Bă̆ımlılı̆̆ı), Altın Kitaplar Yay. İstanbul 1983. KÜRÇAY, Ali, Haşhaş Yetiştirilmesi, Güven Matbaası, Ankara 1962.

KÜTÜKOĞLU, Mübahat, Osmanl-Inniliz Ikktisadi Münasebetleri I (1580-1938), Ankara 1974. Osmanlı-Ingiliz İktisadi Münasebetleri II (1938-1850), Ankara 1976.

MOSSENSOHN, Miri Shefer, Ottoman Medicine: Healing and Medical Institutions, 1500-1700, NY Suny Press, New York Albany 2009.

ÖGEL, Kültegin, Bă̆ımlılı̆̆ Önleme Anne-Babalar Öğretmenler Iç̧in Kılavuz, IQ Kültür Sanat Yayınları, İstanbul 2001.

Sigara, Alkol ve Madde Kullanım Bozuklukları: Tanı, Tedavi ve Önleme, Yeniden Yayınları, İstanbul 2010.

PAMUK, Şevket, 19. Yüzyılda Osmanlı Dış Ticareti, Ankara 1995.

QUATAERT, Donald, Anadolu'da Osmanlı Reformu ve Tarımı (1876-1908), çev. Nilay Özok Gündoğan ve Azat Zana Gündoğan, Türkiye İş Bankası Kültür Yayınları, 2008.

SCHIVELBUSCH, Wolfgang, Keyif Verici Maddelerin Tarihi, Çev. Zehra Aksu Yılmazer, Genesis Kitap Yayınları, Ankara 2012.

SÖZER, Sabri, Uyuşturucu Maddeler ve Problemleri, Ankara 1956.

STEVENS, Alex, Drugs, Crime and Public Health (The Political Economy Of Drug Policy), Routledge İs An İmprint Of The Taylor \& Francis Group, New York 2011.

VATANDAŞ, Celalettin, Türkiye'de Gençlik ve Uyuşturucu Madde Sorunu, Sosyal, Ekonomik ve Kültürel Araştırmalar Merkezi (SEKAM) Yay., İstanbul 2015.

\section{Süreli Yayınlar}

AĞIRAKÇA, Ahmed, “Osmanlı Tıbbının Kaynakları”, Osmanlılarda Sağlık, Cilt: I, Health in The Ottomans, Editör: Coşkun Yılmaz-Necdet Yılmaz, Biofarma Yayınları, İstanbul 2006. s. 133-165.

ALTAN, Suna, "Cenevre Afyon Konferansları ve Türkiye'nin Tutumu", Çanakkale Araştırmaları Türk Yıllı̆̆, Bahar 2019, S. 26, s. 45-70.

BAKTIR, Mustafa, "Afyon", DIA, C. 1, TDV Yayınları, İstanbul 1988, s. 442-443.

BAŞOĞLU, Tuncay, "Uyuşturucu", Türkiye Diyanet Vakf İslam Ansiklopedisi (DİA), Türkiye Diyanet Vakf1 Yayınları (TDV), C. 42, İstanbul 2012, s. 248-253.

BAYRAKTAR, Köksal, "Uyuşturucu Maddeler ve Suç Siyaseti", İstanbul Üniversitesi Hukuk Fakültesi Mecmuast, C. LI, S. 1-4, 1985, s. 45-64.

BAYTOP, Turhan, "Eczacıl1k", DİA, C. 10, TDV Yay., İstanbul 1994, s. 386-388.

"Esrar", DIA, C. 11, TDV Yay., İstanbul 1995, s. 431-432.

BERRIDGE, Virginia, "Two Tales of Addiction; Opium and Nicotine", Human Psychopharmacology, Vol. 12, London 1997, p. 45-52. 
BROOKOFF, Daniel; CAMPBELL, Elizabeth A.; SHAW, Leslie M., "The Underreporting of Cocaine-Related Trauma: Drug Abuse Warning Network Reports vs Hospital Toxicology Tests", American Journal of Public Health, Volume 83, Issue 3, p. 369-371.

ÇITIR, Burak, "Uluslararası Afyon Anlaşmalarında Osmanlı İmparatorluğu", Sosyal ve Kültürel Araştırmalar Dergisi, C. I, S.1, 2015, s. 17-47.

ÇOLAK, Filiz, "Anadolu'da Afyon Ziraati ve Ticaretine Dair İzlenimler", The Journal of Academic Social Science Studies, V. 6/1, January 2013, s. 513-529.

DOĞUKAN, Rıza, “Türkiye'de Haşhaş Ziraatı ve Afyon İstihsali”, Ziraat Dergisi, S. 97, 1949, s. 31-55.

GENÇ, Mehmet, "Yed-i Vâhid", DİA, C. 43, TDV Yay., İstanbul 2013, s. 378-383.

HAMARNEH, Sami, "Pharmacy in Medieval Islam And The History of Drug Addiction", Medical History, Volume 16, Issue 3, 1972, p. 226-237.

KALA, Ahmet, Esnaf, DİA, C. 11, TDV Yay., İstanbul 1995, s. 423-430.

KILIÇ, Rüya, "Afyonun Keyfini Tiryakisinden Sormalı": Osmanlı ve Erken Cumhuriyet'te Madde Bağımlılığı Tarihi", Kebikeç. S. 42, 2016, s. 147-179.

KÜTÜKOĞLU, Mübahat, "Baltalimanı Muahedesi”, DIA, TDV Yay., C. 5, İstanbul 1992, s. 3840.

MAT, Afife, “Osmanlı İmparatorluğu'nda Afyonun Tarihi”, Osmanlı Bilimi Araştırmaları, XI/ 1-2, 2009-2010, s. 285-290.

PAMUK, Şevket, "Money İn The Ottoman Empire 1326-1914”, An Economic and Social History of the Ottoman Empire 1300-1914, Ed. Halil İnalc1k ve Donald Quataert, Cambridge Univ. Press, 1996, s. 947-1026.

QUATAERT, Donald, “The Ages Of Reforms 1812-1914”, An Economic and Social History of the Ottoman Empire 1300-1914, Ed. Halil İnalc1k ve Donald Quataert, Cambridge Univ. Press, 1996, s. 759-946.

SEDDON, Toby, "The Regulation of Heroin: Drug Policy And Social Change İn Early Twentieth-Century Britain", International Journal Of The Sociology Of Law, Volume 35, Issue 3, September 2007, p. 143-156.

TAŞDEMIR, Mehmet, "Karadeniz Bölgesinde Kendir-Keten Üretimi ve Kullanım Alanları", Türk Kültürü Incelemeleri Dergisi, Say1 8, İstanbul 2003, s. 1-24.

TAŞLIGIL, Nuran ve ŞAHIN, Güven, "Tarihsel Süreçte Haşhaş ve Afyon", Tarih Okulu Dergisi, S. XXXIV, Haziran 2018, s. 163-196.

TOPRAK, Süleyman, “Mizan”, DIA, C. 30, TDV Yay., İstanbul 2005, s. 211-212.

ULUSKAN, Murat, "İstanbul'da Bir Afyonlu Macun İşletmesi: Berş-i Rahîkî Macunhanesi (1783-1831)”, Türk Kültürü İncelemeleri Dergisi, S. 29, İstanbul 2013, s. 77-106.

\section{Internet Kaynakları}

TÜRK DİL KURUMU (TDK), htpp://tdk.gov.tr/Erişim Tarihi 15/11/2019.

WORLD HEALTH ORGANIZATION (WHO), https://www.who.int/health-topics/drugs/Erişim Tarihi 15/12/2019. 